\title{
Reproductive Performance of Water Buffalo Cows: A Review of Affecting Factors
}

\author{
Hector Nava-Trujillo ${ }^{1, *}$, Robert Valeris-Chacin ${ }^{2,3}$, Adriana Morgado-Osorio ${ }^{1}$, \\ Simón Zambrano-Salas ${ }^{4}$, Luis Tovar-Breto ${ }^{5}$ and Armando Quintero-Moreno ${ }^{6}$
}

\author{
${ }^{1}$ Producción Animal, Instituto de Investigaciones Agropecuarias, Facultad de Ciencias Forestales y \\ Ambientales, Universidad de los Andes, Mérida, Mérida, Venezuela \\ ${ }^{2}$ Departamento de Sanidad Animal y Salud Pública, Facultad de Ciencias Veterinarias, Universidad del Zulia, \\ Maracaibo, Zulia, Venezuela \\ ${ }^{3}$ Department of Veterinary and Biomedical Sciences, College of Veterinary Medicine, University of Minnesota, \\ Saint Paul, Minnesota, USA \\ ${ }^{4}$ Departamento de Ciencias Agrarias, Núcleo Universitario Alberto Adriani (NUAA), Universidad de los Andes, \\ El Vigía, Mérida, Venezuela \\ ${ }^{5}$ Genética y Embriones Mérida C.A., Mérida, Mérida, Venezuela \\ ${ }^{6}$ Laboratorio de Andrología, Unidad de Investigación en Producción Animal (UNIPA), Facultad de Ciencias \\ Veterinarias, Universidad del Zulia, Maracaibo, Zulia, Venezuela
}

\begin{abstract}
This article aims to review both the economic impact of reproductive failures on the profitability of water buffalo systems and the effect of different factors on the reproductive performance of water buffaloes. Besides, an overview of various non-hormonal alternatives to improve reproductive performance is made. The optimal reproductive efficiency in water buffaloes implies calving to conception interval around 90 days to reach a calving interval of 400 days, with longer calving intervals having a negative impact on profitability. Reproductive efficiency is the consequence of the interaction of genetic and non-genetic factors, and the recognition of these factors by analyzing the reproductive information must be a priority. Although each factor's impact can be of greater or lesser magnitude depending on the conditions of each herd, some factors like nutrition, milk yield, body condition score, negative energy balance, parity, bull presence, low estrus intensity, and season can be considered high-impact factors. Not all factors are common among farms; therefore each farm must implement a program for the identification, control, and prevention of reproductive problems, especially during early lactation, to prevent a long anestrus; and when artificial insemination is used, so that it is done at the correct time with respect to the beginning of estrus to enhance fertility.
\end{abstract}

Keywords: Parity, season, BCS, energy balance, milk yield, silent estrus, anestrus.

\section{INTRODUCTION}

The world population of buffaloes (Bubalus bubalis) has increased steadily, and there is currently more than 200 million head [1,2]. In the American continent, the water buffalo population has increased by $26.4 \%$ between 2005 and 2016 [1], exceeding 5 million head [3]. This dynamic may be due to the better adaptation of the species to the hot and humid climate of the tropical areas at the north of the Equator compared to cattle of European origin and to the higher market price of their milk, which contributes to higher profitability of buffalo milk production [4]. In Venezuela, buffalo milk's price may be $40 \%$ higher than that of cow's milk, while in Italy, it can be between two and three times greater $[5,6]$. However, to maximize this profitability, it is

*Address correspondence to this author at the Producción Animal, Instituto de Investigaciones Agropecuarias, Facultad de Ciencias Forestales y Ambientales, Universidad de los Andes, Mérida, Estado Mérida, Venezuela; Tel: +58 414748 1810; E-mail: hectornava00@gmail.com necessary to achieve good reproductive performance by controlling the duration of the calving interval $(\mathrm{Cl})$ $[7,8]$, whose economic optimum is around 400 days $[7,9,10]$.

The $\mathrm{Cl}$ depends on the calving to conception interval and has a correlation of $0.90-0.99$ with this parameter $[11,12]$. In turn, the calving to conception interval is regulated by the voluntary waiting period, the calving to first service interval, and fertility, which will be the factors to control to reach the optimal $\mathrm{Cl}$ [13]. A longer interval to first estrus or mount and a high incidence of anestrus [14-17] could be the leading causes of long $\mathrm{Cl}$ observed in different studies $[10,11,18,19]$. However, despite this situation, in buffalo farms managed under natural service, the use of other parameters in addition to the $\mathrm{Cl}$ remains scarce. This implies a limitation to make an accurate diagnosis of the herd's reproductive situation, compromising the identification of risk factors to reproductive failures and limiting alternative solutions. The $\mathrm{Cl}$ is not a very useful 
parameter and does not show the herd's current reproductive situation, since it can only be calculated in the females calving again, excluding the nulliparous and first calving; and those to which it is decided to not service [13]. The $\mathrm{Cl}$ is a historical parameter that identifies the reproductive problem late and therefore hinders its prevention and early correction.

Obtaining an interval to the conception of 90 days and consequently, a $\mathrm{Cl}$ close to 400 days must be a priority for farmers, and this depends on management conditions and reproductive practices $[20,21]$. Several factors influence the achievement of these reproductive goals. Therefore, the objectives of this article are to review the impact of a long calving interval on the profitability of buffalo production systems and how different factors affect the reproductive performance of water buffaloes. Additionally, a review of non-hormonal alternatives to improve the reproductive performance of water buffaloes is presented.

\section{ECONOMIC IMPACT OF A LONG CALVING INTERVAL}

Reproductive performance has the most significant impact on system profitability [8]. Optimum $\mathrm{Cl}$ is around 400 days $[7,9,10]$, and long Cls involve losses due to decreased milk production per year, an increase of non-productive days, feeding costs, delayed replacement of animals, sale of potentially productive animals, and a delay in the genetic progress of herds. Economic losses generated by anestrus were calculated at $5.53 \mathrm{USD} / \mathrm{day} /$ buffalo [22]. Khan et al. [10] reported a decrease in economic return between 24 and $27 \%$ for water buffaloes with longer calving to conception interval; while the increase in the $\mathrm{Cl}$ caused a decline in milk production of $2.1 \mathrm{~kg}$ per day when it increased from 365 to 635 days [9] and a negative correlation between $\mathrm{Cl}$ and milk production per day of $\mathrm{Cl}$ has been reported [18]. More recently, it was determined that the cost of each additional day of $\mathrm{Cl}$ after 365 days, was 6.07 USD [23] and that each additional day over the average $\mathrm{Cl}$ implies a decrease in earnings of 1.87 USD [24]. However, it is necessary to evaluate how reproductive strategies, like out-ofbreeding mating strategy, a practice to change the calving calendar, and increases milk offer during months with long photoperiod when water buffaloes have low reproductive activity [69], but this reproductive strategy produces a decrease of fertility and an increase of calving interval, affecting the economic performance of water buffalo systems.

\section{FACTORS AFFECTING THE REPRODUCTIVE} PERFORMANCE OF WATER BUFFALO COWS

\subsection{Genotype}

The genotype has an important effect on the reproductive performance of buffaloes, contributing $77.61 \%$ in the total variation of $\mathrm{Cl}$ [25], which coincides with Kumar et al. [26], who suggest that, although more research is needed, genetic factors could affect the variation of postpartum anestrus period. Sanker et al. [25] observed that Murrah buffaloes had a shorter $\mathrm{Cl}$ (424.32 \pm 2.60 days, $P<0.05)$ compared to Diara buffaloes $(464.21 \pm 2.57)$ or those genetically not described (462.19 \pm 2.55 days). Christa Charlini and Sinniah [27] observed significant differences in the $\mathrm{Cl}$ between Nili-Ravi and Surti buffaloes. In Bhutan, Murrah crossbred buffaloes reached the first calving younger and achieved a shorter first $\mathrm{Cl}$ than local buffaloes of genotype not described [28]. In Venezuela, there was no effect of the breed on the calving to first service interval. However, it was observed in the calving to conception interval and $\mathrm{Cl}$, with buffaloes of undetermined genotype presenting a better performance (102.68 \pm 3.32 days and $427.18 \pm 13.57$ days, respectively) compared to those predominantly Murrah $(132.91 \pm 2.35$ days and $445.08 \pm 8.09$ days, respectively) or the Mediterranean (137.72 \pm 11.65 days and $452.01 \pm 8.38$ days, respectively) [29]. Recently, it has been observed that F1 Italian x Egyptian or $3 / 4$ Egyptian $1 / 4$ Italian buffaloes, had a lower incidence of calvings with difficulty and needing veterinary assistance and lower incidence of stillbirths compared to those of pure Egyptian, this could be related to the higher birthweight of pure Egyptian calves or the absence of genetic selection to improve the easy calving; in addition, it was observed than pure Egyptian buffaloes had lower first service fertility than $3 / 4$ Egyptian $1 / 4$ Italian buffaloes [30]. The breed affected the age at the first calving, with Mediterranean buffaloes being younger $(37.81 \pm 0.35$ months, $P<0.05)$ than Murrah buffaloes $(39.16 \pm 0.26$ months) or those with undetermined genotype (40.35 \pm 0.72 months) [29]. Differences in reproductive efficiency between genotypes could be due to the difference in adaptation capacities to different environments and the different genetic merit to milk yield [30,31]. F1 Italian/Egyptian, which produced more milk at 305 days than the $3 / 4$ Egyptian $1 / 4$ Italian or pure Egyptian buffaloes, had a longer interval to conception and more services per conception [30].

Some genes have been associated with the reproductive efficiency of buffaloes. The $C C, A A$ and 
GG genotypes of the CYP191A gene, which encode the cytochrome $\mathrm{P} 450$ aromatase enzyme that regulates estrogen synthesis, and the C, A and G alleles, are associated with a higher risk of anestrus [32]. Moreover, haplotypes containing two or three of these alleles are related to low levels of estrogen and antioxidant enzymes in blood and at a low expression of the CYP191A, alpha estrogen receptor, and glutathione peroxidase 3 enzyme genes in ovarian tissue [32]. Additionally, the GG genotype of the leptin gene was associated with a higher number of services per conception (3.67, $\mathrm{P}=0.03$ ) compared to the AA (2.19) and AG (2.65) genotypes, and this could be related to the fact of that buffalo with the GG genotype gave birth to heavier calves [33]. Also, de Camargo et al. [34] identified genes related to the age at first calving, calving interval, services per conception, and open days, while Li et al. [35] identified 25 genes associated with follicle development.

\subsection{Age at First Calving}

Age at first calving has an important impact on the profitability of farms and is a good indicator of the reproductive performance of the herd [36]. The costs related to the management of the females can amount to up to $20 \%$ of the total costs of the farm [37]. Therefore, getting females to reach their first calving younger should be a priority given that it allowed for reduced costs related to feeding and increased the income from milk and calf production [38]. In Venezuela, $38.9 \pm 0.51$ months of age at first calving was recently reported [29]. However, there is little information in the scientific literature on the effect of age at first calving on the reproductive performance of water buffaloes. Zicarelli [39] observed that the older buffaloes at first calving had a longer $\mathrm{Cl}$. Verma et al. [36] observed that the youngest buffaloes at first calving (34.65 months) had a 31.85 days shorter service period and 44.2 days less in $\mathrm{Cl}$, than the older buffaloes at the first calving (54.21 months), although, these differences were not statistically significant. Reduced age at first calving depends on genetic selection and diet that decreases the age at puberty and allows reaching the weight for incorporation into the mating program at a younger age. It was observed in Italy that the age at first calving decreases one month every five years [39]. At first calving, age was 28-32 months when buffalo heifers received a diet with $1700 \mathrm{kcal}$ NEL and $12-13.5 \%$ of crude protein and [39]. Sabia et al. [40] reported a negative correlation between daily weight gain and age at puberty $(r=$ 0.299, $\mathrm{P}<0.01)$. Hussein and Abdel-Raheem [41] subjected a group of heifers to two diets and observed that those with the highest feeding level reached the first service younger (30.8 \pm 1.6 months), heavier $(340.1 \pm 3.5 \mathrm{~kg})$ and had higher fertility $(87.8 \%)$ than those managed in a low feeding plane $(35.3 \pm 1.1$ months; $312.4 \pm 4.2 \mathrm{~kg}$ and $10 \%$, respectively).

\subsection{Calf Sex}

Christa Charlini and Sinniah [27] did not observe a significant effect of calf sex on the $\mathrm{Cl}$; however, in Venezuela, Montiel Urdaneta [42] reported longer calving to conception interval and $\mathrm{Cl}$ for buffaloes whose calves were male (71.84 days and 388.22 days respectively, $\mathrm{P}<0.01)$ compared to those with female calves (54.13 days and 370.04 days respectively). Khan et al. [43] observed that both cows and buffaloes with male calves had longer calving to conception interval, and this coincides with Kantharaja et al. [44] who observed that buffaloes with male calves had longer calving to first service interval and calving to conception interval. Amjad et al. [45] observed that buffaloes with male calves had a higher incidence of reproductive disorders (dystocia, fetal membrane retention, and uterine prolapse), and this was related to the higher weight of the males.

\subsection{Suckling}

In several species, suckling delays the onset of postpartum reproductive activity. El-Fouly et al. [46] reported that buffaloes who nursed their calves had the first postpartum ovulation at 87 days, while those weaned ovulated for the first time at 51.6 days, the delay being longer in primiparous buffaloes (66 days) than in multiparous (45 days). Suckling caused a decrease in the percentage of buffaloes that showed estrus in the first 60 days postpartum, with calving to first estrus interval of 131.5 days for buffaloes suckling and 77.9 for weaned, with a higher negative impact on primiparous. Qureshi and Ahmad [14] observed a positive correlation between the days of duration suckling period and the interval at the first ovulation $(r=$ $0.19, P<0.01)$ and the first estrus $(r=0.23, P<0.01)$, with buffaloes suckling for a maximum of 30 days having a shorter interval to the first ovulation and estrus than those with longer suckling period. Rijasnaz et al. [47] observed that suckling reduced cyclicity and pregnancy in the first 150 days postpartum, causing a longer interval to estrus and conception (128 \pm 9.94 days and $143.50 \pm 5.50$ days, respectively) compared to buffaloes that did not suckle their calves (53.29 \pm 7.52 days and $75.67 \pm 10.16$ days, respectively, $\mathrm{P}<$ $0.05)$. 
Furthermore, Kantharaja et al. [44] reported that weaned buffaloes had a shorter interval to first estrus (62.50 \pm 1.50 days) compared to those that suckled their calves $(99.25 \pm 9.15$ days, $P<0.05)$. The mechanism by which suckling delays the onset of reproductive activity is complex and implies decreased LH secretion and, consequently, a delayed follicular development [48]. These adverse effects could be mediated by cortisol and can occur even with the offspring's mere presence, without the need for physical contact [49].

\subsection{Parity}

Parity has a determining effect on reproductive efficiency [11,12,17-19,25,26,50-54]. Sosa et al. [16] observed that the incidence of anestrus was higher in first calving water buffaloes $(21.59 \%)$ compared with those of two $(11.63 \%)$ and those of three or more calvings $(9.97 \%)$ and this implies a lengthening of the calving to first estrus and calving to conception intervals. These results coincide with those observed in Venezuela, where the primiparous water buffalo had an interval at first mount 30 days longer than multiparous. They were also less likely to be mounted for the first time at both 60 and 100 days postpartum [17]. Firstcalving buffaloes had a higher rate of stillbirths [55] and lower pregnancy rates than multiparous [54], and the latter agrees with the longer $\mathrm{Cl}$ observed in primiparous. Primiparous water buffaloes had a $\mathrm{Cl}$ of 43 and 79 days [18] and 35.3 and 55.5 days [19] longer than those with two and three or more calvings, respectively $(P<0.05)$. The lengthening of the $\mathrm{Cl}$ in primiparous buffaloes could be a consequence of a longer anestrus period, a higher number of open days and services per conception [56,57]. This could be related to the level of milk yield [19], and probably with the fact that primiparous water buffaloes have a higher negative energy balance and higher levels of stress, which can affect the onset of postpartum reproductive activity, without ruling out inappropriate management [58-60]. Additionally, parity affects the pregnancy rate after the Ovsynch protocol and fixed-time artificial insemination. Primiparous buffaloes had lower pregnancy rate $(20.8 \%$ and $30.8 \%)$ than multiparous (61.7 and $72.4 \%, P<0.05$ ) [61].

\subsection{Season of Calving}

Water buffaloes are a short-day species, and season of calving affects their reproductive performance $[17,19,52,62-66]$. Buffalo cows calving in months of short photoperiod has an early onset of reproductive activity and shorter calving to conception interval and, therefore, a shorter $\mathrm{Cl}$ than those that calving during long photoperiod season $[53,63]$. Buffalo cows calving during the long photoperiod season (March-August) have a more extended period of anestrus and are less likely to have their first mount before 60 and 100 days postpartum ( 0.134 and 0.312 respectively, $\mathrm{P}<0.05$ ) compared to those calving during the short photoperiod season (SeptemberFebruary; 0.354 and 0.536 , respectively), when mounts were more frequent (70.6\%) [17]. Rossi et al. [67] observed that buffaloes calving during OctoberDecember, when daylight decreases, had a higher probability of pregnancy after an Ovsynch protocol and fixed-time artificial insemination than those calving during the rest of the year. Buffalo cows ovulating during the long photoperiod season, have a higher rate of silent estrus, smaller follicles, lower estrogen levels, and irregular cycles, as well as lower levels of progesterone, lower embryo quality, higher early and late embryo death, a higher rate of repeat breeding and lower fertility [68-71]. In Venezuela, buffaloes calving between December and March or April and July had a longer $\mathrm{Cl}$ (452.2 and 450.6 days, respectively) than those calving between August and November (435.6 days, $P<0.05$ ) [19]. Recently, lower pregnancy rates have been reported during spring/summer than during autumn/winter [54,72,73]. Some of these consequences are related to the increase in prolactin levels observed during the long photoperiod season, which are related to a decrease in gonadotropin secretion, a decrease in the follicular steroidogenic capacity, generating anestrus and infertility [74,75]. Additionally, during the long photoperiod season, the corpus luteum receives lower blood flow, which compromises its ability to produce progesterone, which is related to embryos of smaller size, which are more prone to embryonic death $[69,76-80]$. The season did not affect buffalo heifer's fertility, probably because they have higher levels of melatonin during the hours of light in comparison with buffaloes, which have previously had a calf $[64,202]$. The better reproductive efficiency observed in the short photoperiod season could be related to the decrease in temperature, relative humidity, and temperature-humidity index (THI) $[53,80]$. Dash et al. [81] observed a negative relationship between $\mathrm{THI}$ and pregnancy rate in Murrah buffaloes, with a significant decrease in this parameter when $\mathrm{THI}$ was higher than 75. A THI $>80$, caused a significant reduction in conception rate at first service compared to a THI $<80$, and consequently this reduction in fertility led to a considerable increase in 
the calving interval $[31,54]$. However, the effect of high $\mathrm{THI}$ on reproductive performance seems to depend on the breed [31]. Nevertheless, the effect of high THI is questionable because, in Italy, fertility improves during July and September, when temperature and THI are higher, and this highlights the role of photoperiod as the main regulator of seasonality [64].

\subsection{Presence and Health of Bulls}

As part of the buffalo management system, the continuous presence of a bull improves reproductive efficiency $[26,82]$. The presence of vasectomized bulls increased the rate of buffalo in estrus, estrus intensity, the rate of ovulatory estrus, and the pregnancy rate in buffaloes in both natural and induced estrus; additionally, these effects were higher during the season of low reproductive activity [83]. The bull's presence between days 40 and 90 postpartum shortened the interval to estrus and ovulation, reduced the percentage of silent estrus, increased progesterone levels, increased fertility at first service, and the percentage of pregnancy at 60 days postpartum [84]. The continuous presence of bulls from day five postpartum, shortened the interval to the first estrus (55.2 \pm 0.78 days, $P<0.05$ ) compared to buffaloes in which the bull presence was intermittent $(66.71 \pm 0.93$ days) or to those buffalo cows exposed to bull urine and feces (68.25 \pm 0.87 days) or control $(68.57 \pm 0.93$ days) [85]. During the season of low reproductive activity in Pakistan, the continuous or partial presence of the bull increased the percentage of buffalo in estrus (60\% and $40 \%$ respectively) and the rate of pregnancy at 60 days post-service ( $40 \%$ and $20 \%$, respectively) in comparison with those unexposed $(5 \%$ and $0 \%$ ) [86]. However, to observe a shortening of the interval to estrus, a bull's continuous presence was necessary [86]. Recently it was determined that the presence of a bull at less than 20 feet shortened the onset of postpartum ovarian activity [26]. Biostimulation's effects could be due to the action of bull pheromones acting on the hypothalamic-pituitary axis to promote the secretion of LH and consequently follicular activity and ovulation and the formation of a competent corpus luteum that secretes higher levels of progesterone favoring the establishment of pregnancy [84].

Different hereditary, congenital, and infectious conditions affect the reproductive potential of buffalo bulls and, consequently, the reproductive performance of the herds [87-89]. Positive correlations were observed between body weight and testosterone levels $(r=0.58 ; P<0.0001)$ and between testosterone and scrotal circumference $(r=0.16 ; P<0.02)$ [90], and low testosterone and nitric oxide levels were associated with poor sexual behavior [91]. Age and season can affect sexual behavior and sperm quality. Adult bulls (48 years) had higher body weight, scrotal circumference, and libido than those younger or older bulls; and theses parameters were higher during the peak breeding season (September-November) [92], and similarly, quality of thawed semen was higher in adult buffalo bulls than young or old bulls, and during the peak than the low breeding season [93]. Old bulls $(13.6 \pm 1.0$ years) had worse sperm quality (lower ejaculate volume, lower viability, and lower DNA integrity) than younger bulls $(3.4 \pm 0.3$ years $)$ [94]. Scrotal circumference and sperm quality are related to nutrition. Bodyweight correlated positively with scrotal circumference, and this with sperm concentration, while intake of crude protein was correlated positively with sperm motility and lipid intake with sperm motility and sperm membrane integrity [95]. Kumar and Srivastava [96] observed a positive correlation between body weight and scrotal circumference, testicular volume, sperm concentration, sperm motility, viability, while a negative correlation with sperm abnormalities was observed.

Nevertheless, Yadav et al. [97] observed than a higher rump fat thickness was associated with a high percent of sperm abnormalities. In addition, it was observed that rump fat thickness was higher in low libido bulls $(7.29 \pm 0.93 \mathrm{~mm})$ than in bulls with a high libido $(5.29 \pm 0.62 \mathrm{~mm}, \mathrm{P}<0.05)$ [98]. Also, the reproductive potential of younger and submissive bulls could be affected by the aggressive behavior of dominant bulls [99]. Moreover, aggressive behavior is the main reason to cull bulls [100]. Scientific literature available about these subjects is scarce, and more research is warranted.

\subsection{Milk Yield}

Few studies have evaluated the relationship between milk yield and reproductive efficiency in water buffalo. El-Belely et al. [101] suggest that milk yield could have a negative effect on fertility. Qureshi and Ahmad [14] observed a positive correlation between milk yield and the calving to ovulation interval $(r=0.31$, $P<0.01)$ and that although buffaloes with higher yield reached a higher conception rate at first service, they needed more days to uterine involution and to first ovulation postpartum. Buffaloes that produced more than $8 \mathrm{~kg}$ of milk per day had a more extended postpartum anestrus period (El-Fadaly [102]: 107 \pm 36 days; El-Azab et al. [103]: $76 \pm 25$ days) than those 
producing less than $8 \mathrm{~kg}$ of milk per day $(77 \pm 30$ days and $56 \pm 24$ days, respectively). Valsalan et al. [104] reported a $0.9 \%$ decrease in pregnancy for each increase of $100 \mathrm{~kg}$ of milk at 305 days, and ElTarabany [54] observed that buffaloes with a daily production higher than $9 \mathrm{~kg}$ of milk, had a lower probability of pregnancy than those producing less than $7 \mathrm{~kg}$ of milk per day. Nava-Trujillo et al. [18], observed a positive correlation between the $\mathrm{Cl}$ and milk yield $(r=$ $0.34983, P<0.0001)$ and with lactation length $(r=$ $0.67408, P<0.0001$ ); and this coincides with Seno et al. [105], who reported a positive correlation between milk yield and the length of first $\mathrm{Cl}$. Moreover, de Camargo et al. [34] observed a positive genetic and phenotypic correlation between milk yield, $\mathrm{kg}$ of fat, $\mathrm{kg}$ of protein; \% of fat, \% of protein and somatic cell score with age at first calving, services per conception, open days and calving interval.

Some studies did not identify relationships between milk production and the reproductive performance of buffaloes [106-109]. Nevertheless, Vilela et al. [110] reported a positive correlation between milk yield and age at first calving and the $\mathrm{Cl}$. These results, together with previous reports $[19,54,103]$, highlight the importance of the proper design of genetic programs to improve milk yield in buffaloes to avoid negative consequences on reproductive efficiency, as previously suggested [67].

The use of oxytocin is common to induce the letdown of milk with mechanical milking [111]. The use of oxytocin at the time of milking increased the calving to the first ovulation interval [14], and more recently a positive correlation has been observed between the use of oxytocin and the postpartum anestrus period [26], and this could be related to its effect on milk production [112] and oxidative stress [113]. Additionally, the use of oxytocin increases the incidence of reproductive problems such as follicular and luteal cysts, retention of placenta, anestrus, and repetition of services [114]. However, given the frequent use of oxytocin at milking and the few studies reporting a negative relationship between oxytocin use and reproductive performance of buffalo cows, more research is warranted to have a greater understanding of the possible effects of this hormone on the different reproductive events in buffaloes.

\subsection{Body Condition Score and Negative Energy Balance}

Body condition is a determining factor in the reproductive performance of buffaloes $[115,116]$. Buffaloes with an intermediate body condition at calving, had a shorter conception interval (128.3 days) than those over-conditioned (144.1 days) or very thin (165.5 days) [117] and this has been recently corroborated [118]. Buffalos with ovarian inactivity had lower body condition score than those with active ovaries $(2.08 \pm 0.11$ vs. $2.88 \pm 0.28)$ [119]; and a higher body condition during the first 90 days postpartum was related to a short interval to first estrus [120] and a higher body condition score at insemination was related with a larger ovulatory follicle, lower progesterone at estrus and a higher estrus intensity [121]. Water buffaloes with a BCS $<2.5$ submitted to 7 CIDR Cosynch protocol had lower pregnancy rate in comparison with those with a BCS > 2.5 [122], and similar results were observed in water buffaloes treated with PGF2a, GnRH or a mix of vitamins, pregnancy rate was higher in buffaloes with a BCS between 2.5 and 3.5 [123]. A lower body condition score is more frequent in older buffalo cows, which could be associated with their lower reproductive performance [228]

After calving, buffalo cows enter in a period of negative energy balance characterized by a decrease in dry matter intake, with a corresponding reduction in weight, body condition score, glucose and insulin levels, and an increase in non-esterified fat acid (NEFAs) and beta-hydroxybutyrate (BHB) levels [124130]. Deka et al. [126] observed a loss in dry matter intake of $22.7 \%$ on the day of calving with respect to pre-calving intake $(9.91 \mathrm{~kg}$ vs. $12.83 \mathrm{~kg}, \mathrm{P}<0.001)$. Bhalaru et al. [131] observed a loss of weight during the first five months of lactation that varied between $1.13 \%$ and $7.65 \%$ of the calving weight, and this loss was related to the weight of the buffalo at calving, with those heaviest losing more weight, it was also observed that the higher intensity of loss occurred during the first postpartum month. Infascelli et al. [132] observed that the percentage of weight loss during the first 60 days postpartum was related to parity, being higher in multiparous (3.8\%) than in primiparous (1.55\%). Abayawansa et al. [125] reported a loss of weight during the first nine weeks postpartum of 14.7 and $14.5 \%$ for buffalo calving in winter and summer respectively; and more recently Reddy et al. [127] observed a decrease in body weight from $625.7 \pm 3.67$ $\mathrm{kg}$ at calving to $551.55 \pm 4.18 \mathrm{~kg}$ at day 90 postpartum, which represents a decrease of $11.85 \%$. Loss of weight and body condition as a result of the decrease in dry matter intake and the increase in energy expenditure for milk synthesis results from the mobilization of fat reserves accumulated during the dry period, with the 
corresponding increase of NEFAs and BHB $[126,127,133-139]$.

The intensity of negative energy balance is related to the level of milk yield $[127,128,132,139,140]$, and this affects the reproductive performance of buffaloes $[125,141]$. In both, primiparous and multiparous buffaloes with a milk yield $>5000 \mathrm{~kg}$, body weight loss was higher $(4.2 \pm 4.6$ and $5.6 \pm 5.1 \%$ respectively) in comparison with those producing $<5000 \mathrm{~kg}$ $(+3.06 \pm 7.6 \%$ and $2.0 \pm 4.0 \%$ respectively) [140]. Buffaloes losing more than $10 \%$ of weight immediately after calving, needed more services per conception (3.38 \pm 0.7 ) and had a longer conception interval (297 \pm 32.54 days) than those losing less than $10 \%$ of their weight $(2.40 \pm 0.81$ services and $207.6 \pm 46.46$ days, respectively) [141]. Huseein et al. [142] observed that buffaloes that became pregnant in the first 75 days postpartum had a higher weight and body condition score during that period and a shortest first service interval $(65.71 \pm 11.31, P=0.03)$ that buffaloes that were not pregnant $(93.20 \pm 9.81)$, the latter also presented lower body condition and lower weight from day 24 postpartum. Banu et al. [143] observed that buffaloes with lower body condition had a longer interval to the first estrus; while Senosy and Hussein [144] observed that both weight, during weeks 4 and 9 postpartum, and body condition, during weeks 4 and 5 postpartum, were higher in pregnant buffaloes than in non-pregnant ones.

The mechanism through which negative energy balance affects reproductive performance is complex and has not been well studied in water buffaloes. Elsayed et al. [145] observed that buffaloes with delayed postpartum ovarian activity ( $>45$ days postpartum) and consequently with a longer conception

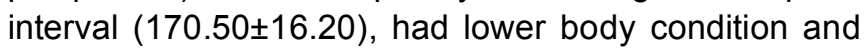
lower levels of IGF-I, glucose, albumin, SOD and GSH, as well as higher levels of NEFAs and BHB during postpartum than those with an early restart of ovarian activity ( $<45$ days postpartum) and a shorter interval to conception (121.60 \pm 15.00$)$. In addition, the levels of NEFAs and BHB were positively correlated with the interval to first ovulation postpartum, while the body condition score and levels of IGF-I, albumin, SOD, and GSH were negatively correlated [145]. These findings indicate that restriction of dry matter intake and the increase of energy demand of milk synthesis during the postpartum period leads to low glucose levels and consequently insulin, that affects the expression of receptors for growth hormone $(\mathrm{GH})$ in the liver, this implies a low hepatic synthesis of IGF-I and an increase in $\mathrm{GH}$ levels and excessive lipolysis. This scenario can affect gonadotropin secretion, follicular growth, and expression of estrus and progesterone levels, as observed in cows [146,147]. Moreover, the negative energy balance can compromise the health of buffaloes. A low body condition was a predisposing factor for the occurrence of endometritis [144], while buffaloes with metritis, endometritis, and mastitis had higher levels of NEFAs and BHB and lower levels of glucose and calcium than healthy buffaloes [148]. Moreover, the predisposition of water buffaloes to reproductive disorders during the early postpartum period could be related to the immunosuppressive state-observed [149]. At least in dairy cows, postpartum immunosuppression is related to negative energy balance [150].

In addition to energy, protein status and mineral deficiencies affect the reproductive performance of water buffaloes. The level of crude protein in the diet was positively correlated with urea in serum $(r=0.22$, $P<0.01$ ), and both were correlated with a longer interval to the first estrus and ovulation postpartum [151]. Campanile et al. [233] did not observe any adverse effect of high urea levels in the blood and vaginal mucus on the reproductive performance of Mediterranean buffaloes, but high blood ammonia could affect the recovery of postpartum body condition score. Nevertheless, it was observed than a level of urea $\geq 6.83 \mathrm{mmol} / \mathrm{L}$ was associated with a reduction in the probability of pregnancy, and buffaloes with lower blood urea had 2.6 times more probability of becoming pregnant [234]. Hypocuprosis is related to a lower level of progesterone, and $21 \%$ of hypocupremic buffaloes had ovarian inactivity, and this could be associated with the lower body condition score, higher level of oxidative stress and lower levels of ceruloplasmin observed in hypocupremic animals [152]. Hafez [153] observed that anestrus buffaloes had lower phosphorus levels and zinc, and a lower ratio of $\mathrm{P}: \mathrm{Ca}$ and $\mathrm{Zn}: \mathrm{Cu}$ than cyclic buffaloes.

\subsection{Diseases}

Several pathologies occurring during the periparturient period generate a reproductive efficiency decrease in water buffaloes. The occurrence of abortion, dystocia, retention of fetal membranes, metritis, endometritis, pyometra, anestrus, repeated breeder, prolapse, and stillborn decrease reproductive efficiency $[55,68,154-156]$. In addition, different infectious [157-166] and non-infectious [167] agents associated with abortions in cows also generate them 
in buffaloes; nevertheless, there are few reports about the reproductive consequences of these pathogens other than abortion in buffaloes. Leptospirosis has been associated with repeated service [168] and neosporosis with the occurrence of repeated service, early losses, and retention of fetal membranes in addition to abortions [166,169]. Water buffaloes infected with Toxoplasma gondii had longer calving to conception interval, while Neospora caninum and Toxoplasma gonddi co-infection was associated with embryo mortality and abortion [166]. Bovine viral diarrhea has been detected in $61.60 \%$ in buffaloes having reproductive problems compared to $8 \%$ in animals without difficulties [170], and their incidence varied according to the pathology: $62.86 \%$ in buffaloes with ovarian inactivity; $51.85 \%$ in buffaloes with endometritis; $60 \%$ in buffaloes with delayed puberty; $58.33 \%$ in repeated breeding buffaloes; $62.50 \%$ in those with retention of fetal membranes, and $66.67 \%$ in buffaloes that aborted [170].

Some traditionally non-reproductive infectious diseases affect the reproductive performance of water buffaloes. Clinical mastitis occurring before the first service increased the conception interval (148.79 \pm 12.66 vs. $76.1 \pm 2.89$ days), being longer when mastitis occurred between the first service and pregnancy diagnosis $(232.47 \pm 17.96$ days, $\mathrm{P}<0.05)$ [171]. More recently, it has been observed that both clinical and subclinical mastitis affect follicular function, reduce estradiol production and conception rate, being as low as $18.18 \%$ in the case of buffaloes with clinical mastitis [172]. The conception rate after estrus synchronization was lower at day 25 and 45 after insemination in buffaloes in clinical $(28 \%$ and $16 \%$ respectively) and subclinical mastitis $(55.56 \%$ and $44.45 \%$ respectively) compared to buffaloes without mastitis $(69.57 \%$ and $60.87 \%$ respectively, $\mathrm{P}<0.05)$. The impact was more significant when mastitis occurred between 15 days before and 30 days after insemination, and this could be a consequence of the reduction in the diameter of the corpus luteum and the production of progesterone observed in buffaloes with mastitis [173]. In addition, parasitic gastrointestinal infection (coccidia and nematodes) reduced pregnancy rate in buffaloes treated with PGF2 $\alpha$ or with a mix of vitamins and minerals $(P<0.05)$ [123]. Haematopinus tuberculatus (pediculosis) caused a lengthening of calving to conception interval [174]. A previous report observed that in water buffaloes with pediculosis, ovarian inactivity was $50.25 \%$, while in cyclic animals with pediculosis, progesterone was lower $(1.63 \pm 0.27$ vs. $2.89 \pm 0.17, \mathrm{P}<0.01)$. Additionally, water buffaloes with pediculosis had lower body condition score, higher oxidative stress, anemia, lymphopenia, eosinophilia, neutrophilia and monocytosis, and lower levels of $\mathrm{Zn}$, $\mathrm{Fe}$, and Se [175]. The prevalence of Fasciola hepatica detected by fecal examination and ELISA was higher in buffaloes with ovarian inactivity compared to cyclic buffaloes $(28.9 \%$ and $38.9 \%$ vs. $4.7 \%$ and $6 \%$, respectively). Fasciola positive buffaloes had higher progesterone levels in the follicular phase of the estrus cycle and different hematological alterations, lower antioxidant capacity, lower levels of serum copper, iron, and selenium [176].

\subsection{Estrus Behavior, Ovarian Structures, and Hormonal Profiles: Relationship with Fertility}

Water buffaloes have low-intensity estrus signs and a high incidence of estrus during the night and silent estrus $[14,143,177,178]$. Estrus has a duration that varies between 5 and 27 hours [179], although during the season of low reproductive activity, the variation is between 2 and 72 hours [180]. Frequent urination, redness, and vulvar edema, and decreased milk production are the most obvious signs [181,182]. The presence of mucus is inconstant, and $52.3 \%$ of the females did not present discharge [183], while the frequency of homosexual behavior is low (3.4\%) [184], so that the best indicator of estrus is the bull's mount [185]. Additionally, between 10 and $63 \%$ of estrus were silent $[83,186-189]$. Both low intensity and silent estrus make it difficult to detect buffalo cows in estrus and compromise the success of artificial insemination programs under natural estrus. Banu et al. [143] observed a low rate of estrus detection (28\%) with a higher number of estrus missed during the first 70 days postpartum and an increase of the interval to the first associated with the number of missed estrus. Buffaloes with intense signs of estrus had a higher conception rate $(81.16 \%)$ in comparison with those with intermediate $(60.47 \%)$ and weak signs of estrus (44.11\%) [190]. Artificial insemination early ( 0 and 12 hours) or late (36 hours) according to the beginning of the estrus reduced the pregnancy rate in comparison to artificial insemination that was carried out 24 after estrus beginning $(26 \%, 37 \%, 13 \%$, and $53 \%$, respectively; $P<0.05)$ [191]. The phenomenon of silent estrus seems to be related to a lower follicular production of estradiol, which depends on the follicular diameter. Awasthi et al. [187] observed that buffaloes with silent estrus had ovulatory follicles of smaller diameter $(7.7 \pm 0.4 \mathrm{~mm}, \mathrm{P}<0.05)$ and with a lower growth rate $(0.7 \pm 0.02 \mathrm{~mm} /$ day, $P<0.05)$ than 
buffaloes with obvious estrus behavior $(11.0 \pm 0.7 \mathrm{~mm}$ and $1.1 \pm 0.1 \mathrm{~mm} /$ day, respectively).

The preovulatory follicle diameter and estradiol levels and the corpus luteum diameter and progesterone levels, are related to fertility in water buffaloes. Pandey et al. [192,193] reported that buffaloes pregnant on day 40 post-ovulation had a preovulatory follicle of larger diameter and higher levels of estradiol at estrus than non-pregnant buffaloes. Furthermore, the conception rate was higher in buffaloes with higher preovulatory follicles [192], and this could be explained by the positive relationship between preovulatory follicle diameter, corpus luteum diameter, and progesterone levels [192,193]. Mansour et al. [173] observed positive correlations between pregnancy rate with corpus luteum diameter and progesterone concentrations at 2, 9, 12, 16, 21, and 25 days post-insemination.

Higher progesterone levels at day five [192,193], ten $[78,80]$ and 12,16 , or 21 [192,193] post-service have been reported in pregnant buffaloes in comparison with non-pregnant; and this highlights the importance of an early increase in progesterone concentration on embryo development and the establishment of pregnancy, and this seems to be related to the diameter of the preovulatory follicle. Pregnant buffaloes whose ovulatory follicles were less than $12 \mathrm{~mm}$ had smaller corpus luteum and produced less progesterone at days 5,12 , and 16 post-ovulation compared to pregnant buffaloes with preovulatory follicles between 12 and $14 \mathrm{~mm}$ or 14 and $16 \mathrm{~mm}$ [193]. Progesterone's importance in the establishment and maintenance of pregnancy is evident during the long photoperiod season when the incidence of embryonic death is higher. In Mediterranean water buffaloes inseminated during the long photoperiod season, those who remained pregnant had higher progesterone concentrations between days 10 and 20 than buffaloes with embryo mortality at day 40 postservice [76]. Low progesterone levels retard embryo growth, and smaller embryos are more likely to suffer embryo mortality. Buffaloes that on day 25 had an embryo with a width $<2.7 \mathrm{~mm}$, which also were shorter compared to embryos with a width $>2.7 \mathrm{~mm}(5.6 \pm 0.4$ $\mathrm{mm}$ vs. $9.0 \pm 0.5 \mathrm{~mm}, \mathrm{P}<0.01$ ), had lower progesterone levels at day 20 [78]. Besides, buffaloes that suffered embryonic mortality on day 45 had smaller embryos on day 25 compared to those that remained pregnant $[78,79]$

\section{ALTERNATIVES TO IMPROVE THE REPRODUCTIVE PERFORMANCE OF WATER BUFFALOES}

There are several alternatives to improve the reproductive performance of water buffaloes and to achieve a conception interval around 90 days; because experimental articles and literature reviews have been published especially regarding the hormonal control of the estrus cycle and ovulation to fixed-time artificial insemination [194-198], in this section some nonhormonal alternatives to improve the reproductive performance of water buffaloes are reviewed.

Feeding management during prepuberal development is critical. Achieving appropriate weight gain is essential for the buffalo to reach puberty, and first calving younger. This, in turn, has been related to a shorter first calving interval [39]. Recently, it was observed that buffalo calves feeding with milk ad libitum by four months has a lower age at first calving (20-26 months); while those receiving more reconstituted milk (150 kg vs. $105 \mathrm{~kg}$ ) had the first calving six months earlier (28.5 vs. 34) [232]. The postweaning daily weight gain has a negative correlation with age at puberty $(r=-0.299, P<0.01)$ and a positive correlation with weight at puberty $(r=$ $0.548, \mathrm{P}<0.01$ ) [40]. Buffaloes with a diet formulated to gain $450 \mathrm{gr} /$ day reached puberty at 24 months, while those with a diet formulated to gain $650 \mathrm{gr} /$ day reached puberty at 21 months $(P<0.05)$ [199]. Hussein and Abdel-Raheem [41] observed that heifers kept with a high energy diet $(8.63 \mathrm{~kg} / \mathrm{dry}$ matter/day, $19.2 \mathrm{Mcal}$ $\mathrm{ME} /$ day, $1.15 \mathrm{~kg} \mathrm{CP/day)} \mathrm{initiated} \mathrm{the} \mathrm{reproductive}$ activity youngest and heaviest and were more fertile than those maintained under a $50 \%$ dietary restriction (4.32 kg/dry matter/day, $9.51 \mathrm{Mcal} \mathrm{ME} /$ day and $0.58 \mathrm{~kg}$ $\mathrm{CP} /$ day). Incorporation of $100 \mathrm{gr} /$ day of mineral mix to the diet of anestrus buffalo heifers (age 42.05 \pm 1.18 months) for four weeks increased the percentage of heifer showing estrus behavior (65\% vs. 33\%) [200]. Furthermore, because buffalo heifers are less sensitive to long photoperiod and exhibit less seasonal reproductive behavior [66,201-203], if proper nutritional management is implemented, it may be possible to incorporate heifers to calve during the start of the long photoperiod and increase milk supply during this season. However, exceptional reproductive management is necessary to avoid a long period of postpartum anestrus and infertility.

In postpartum buffaloes, it is necessary to improve the dry matter and energy intake to reduce the weight 
and body condition score loss to improve reproductive performance and diminish the incidence of diseases, emphasizing primiparous and buffaloes with high milk yield [19]. Proper grazing management is necessary since a high density of animals per hectare can diminish the supply of grass and compromise pregnancy [204]. Supplementation of primiparous water buffaloes with propylene glycol or calcium propionate during the pre and postpartum periods reduced the negative energy balance. It shortened the interval to first estrus $(53.50 \pm 3.69$ and $48.50 \pm 2.79$ days respectively) and conception (63.33 \pm 6.66 and $52.17 \pm$ 2.70 days respectively) in comparison with control $(82.33 \pm 6.70$ and $128.50 \pm 15.39$ days respectively $)$ [205]. In addition, the inclusion of $S$. cerevisiae in the diet reduced fat mobilization [206], and in multiparous water buffaloes, it was observed by reduced days to the first estrus, improve fertility and reduce open days as a consequence of an improvement in the energy status [207]. Increased energy density in the diet using protected fat reduced the calving to conception interval [208], while supplementation with flaxseed reduced PFG2 $\alpha$ secretion, increased progesterone level, and improved pregnancy rate after estrus synchronization [207]. Vitamin E, selenium and niacin has been observed to reduce postpartum anestrus $[210,211]$ and oral administration of vitamins $A, D 3$, and $E$ from four weeks prepartum until the seventh week postpartum decreased the level of NEFAs at week 5 and 7 postpartum, improved the quality of vaginal mucus, decreased the incidence of subclinical endometritis and decreased the open days in comparison with the control group $(97.50 \pm 15.75$ vs. $152.1 \pm 24.45)$, all this was accompanied by decreases in oxidative stress of treated buffaloes [137]. The shortening of the dry period to < 60 days increased the capacity of adaptation of water buffaloes to postpartum metabolic and hormonal adjustments, decreasing the negative energy balance, meaning less of weight and BCS and lower levels of NEFAs and higher levels of glucose, and in consequence, a shortened interval to conception [138,212].

When natural service is used, adult bulls with similar age, size, and body weight (to minimize dominance/subordination), with high scrotal circumference, and in positive energy balance and with a positive qualification after the breeding soundness evaluation, must be selected. Balanced energy, protein, and mineral nutrition are necessary to improve the bulls reproductive performance in short photoperiod when estrus activity is higher, and during the long photoperiod season if bulls are introduced to reduce the seasonal anestrus by biostimulation. In young buffalo bulls, a specific mineral formulation designed for buffaloes increased scrotal circumference and sperm quality compared to those receiving a mineral mix specific to dairy and beef cattle [213]. Palm kernel cake increased testosterone secretion [90], while parental application of tonophosphan, oral zinc, or ascorbic acid increased scrotal circumference, testicular volume, reduced reaction time, improved sperm quality, and conception rate [214]. These could serve as supportive therapy to bulls with low libido or before the beginning of the reproductive season.

A preventive medicine program is also recommended to reduce the incidence of different bacterial and viral diseases, including those that have not been traditionally considered to impact the reproductive performance of water buffaloes (mastitis, hemoparasites, ectoparasites, and gastrointestinal parasites). Treatment of pediculosis with alphacypermethrin, especially during early lactation, improved milk yield, BCS, and shortened the calving to conception interval [174]. In addition, controlling the suckling period duration could reduce the duration of postpartum anestrus period and the incidence of this pathology and improve fertility. Weaning immediately after calving [215] or at day three postpartum [47] or the substitution of calves with a synthetic dummy calf [215] reduced postpartum anestrus, the calving to conception interval, and improved fertility and pregnancy rate. Given the low number of studies about the effect of weaning on the reproductive performance of buffalo cows and health of calves; the age at weaning and weaning system must be considered carefully because weaning could have a negative impact on calf health [216].

In those systems, whose main objective is milk production, the use of sexed semen to produce female calves, because their lower birth weight, could contribute to improving reproductive efficiency. A program of genetic selection for fertility must be implemented. Calving interval has a low heritability $[12,105,217]$, and it is not a parameter to be considered a selection criterion. However, some authors suggest that despite having a low heritability, it should be a criterion to include in genetic programs due to its impact on buffalo production systems $[8,24]$. In addition, new phenotypes for better fertility could be used for selection. In dairy cows, selection based on estrus cyclicity, estrus expression, and absence of silent ovulation has been proposed to improve fertility 
[218]. Considering that anestrus, low estrus intensity, and silent estrus are a significant problem in water buffaloes, selection by these phenotypes could be useful. In seasonal dairy cows, it was observed that selection for a shorter gestation length increased cow's chances to be mated early in the season and calve early [219], and heritability of gestation length in cattle range from 0.33 to $0.62[235,236]$. Given that gestation is longer than dairy cows in water buffaloes, selection by a negative breeding value to gestation length could be evaluated. Recently in two studies, a negative relationship between anogenital distance and pregnancy rate in dairy cows was observed $[220,221]$. This could be considered a new phenotype for genetic selection for higher fertility, and in dairy cows, the heritability of anogenital distance was $0.37 \pm 0.08$ [222]. The selection of dairy cows for a higher body condition score improved health and fertility [223,224,225], and dairy cows with positive genetic merit to fertility had a higher dry matter intake and kept a higher body condition score [226]. These phenotypes are associated with a better adaptation to lactation, and their inclusion in the genetic program is important, especially when a higher milk yield is the central goal. This recent information about potential phenotypes, in addition to the identification of new candidate genes to improve reproductive performance warrants more research in water buffaloes.

Other strategies to improve reproduction could include better management of heat stress and estrus detection. Calving to conception interval was higher, and conception rate lower during months with higher $\mathrm{THI}$ [81]. Incorporation of swimming pools and other strategies to mitigate heat stress could improve reproductive performance $[227,228]$. In order to improve the detection of buffaloes in estrus and to carry out the insemination at the right moment to improve the fertility, more time for observation especially during the cooler part of the day and night hours $[143,229,230]$, the use of teaser bulls [83], or different devices for automatic detection of estrus [231] could be useful. However, if the farm's purpose is to keep a uniform milk supply throughout the year, it is necessary to incorporate technologies such as the synchronization of estrus and ovulation and fixed-time artificial insemination to change the calving calendar [64]

\section{CONCLUSIONS}

Optimal reproductive efficiency in water buffaloes implies calving to conception interval near 90 days to maximize herds profitability by decreasing the losses caused by reproductive failures and decreased milk yield. Achieving these goals should be based on an improvement of the information analyzed. That should include more than the dates of calving and dry-off to improve the evaluation of reproductive efficiency and the identification of risk factors for both failure and reproductive success. While, the factors that affect the achievement of reproductive goals are numerous and some factors act concomitantly; primiparity, calving in the long photoperiod season, high milk yield, low body condition and a negative energy balance, estrus detection, and presence of a healthy bull, should receive more attention. Additionally, a special management program must be designed to reduce delay in the onset of postpartum ovarian activity and the lengthening of calving to conception interval. Each farm should implement a reproductive epidemiology program that facilitates the identification, control, and prevention of reproductive problems. Different nonhormonal alternatives are available to reach an improvement in reproductive performance. Moreover, a genetic improvement program, including the selection by phenotypes and genes associated with better reproductive performance, could be implemented.

\section{CONFLICT OF INTEREST}

The authors declare that they have no conflicts of interest.

\section{ACKNOWLEDGEMENTS}

Authors would like to thank the Centro de Estudios Superiores e Investigación en Ciencia Animal (CESICA) (La Fria-Táchira, Venezuela) financial support. We also thank Dr. Thomas Gaydos (Gaydos Technical Services, LLC, Dallas-Texas) for reading and correcting our manuscript.

\section{REFERENCES}

[1] Borghese A, Boselli C, Terzano GM. Planetary impacts of dairy buffalo. Proceedings of $11^{\text {th }}$ World Buffalo Congress, 2016: Cartagena de Indias, Colombia. 2016; pp 1-5.

[2] Zhang Y, Colli L, Barker SF. Asian water buffalo: domestication, history and genetics. Animal Genetics 2020; 51(2): 177-191. https://doi.org/10.1111/age.12911

[3] Crudelli GA, Konrad JL, Patiño EM. Situación de la bubalinocultura en países americanos. In: Crudelli GA, Konrad JL, Patiño EM, editors. Reproducción en Búfalas. 1st edition. Argentina: Moglia Ediciones 2016; p. 235.

[4] Menghi A, Corradini E, De Roest K. Profitability of buffalo's milk in the province of Latina (Italy) in 2004 and 2005. Ital J Anim Sci 2007; 6(Supp 2): 1390-1393. https://doi.org/10.4081/ijas.2007.s2.1390 
[5] Tiezzi F, Cecchinato A, De Marchi M, Gallo L, Bittante G. Characterization of buffalo production of northeast of Italy. Ital J Anim Sci 2009; 8(Suppl. 3): 160-162. https://doi.org/10.4081/ijas.2009.s3.160

[6] Borghese A. Buffalo livestock and products in Europe. Buffalo Bulletin 2013; 32(Special Issue 1): 50-74.

[7] Shah SNH. Prolonged calving intervals in the Nili Ravi buffalo. Italian J Anim Sci 2007; 6(Suppl 2): 694-696. https://doi.org/10.4081/ijas.2007.s2.694

[8] Sweers W, Mohring T, Muller J. The economics of water buffalo Bubalus bubalis breeding, rearing and direct marketing. Archiv fur Tierzucht 2014; 57: 1-11. https://doi.org/10.7482/0003-9438-57-022

[9] Shah SNH, Dijkhuizen AA, Willemse AH, Van der Wiel DFM. Economic aspects of reproductive failure in dairy buffaloes of Pakistan. Prev Vet Med 1991; 11: 147-155. https://doi.org/10.1016/S0167-5877(05)80036-4

[10] Khan S, Qureshi MS, Ahmad N, Amjed M, Durrani FR, Younas M. Effect of pregnancy on lactation milk value in dairy buffaloes. Asian-Australas J Anim Sci 2008; 21: 523531.

https://doi.org/10.5713/ajas.2008.70349

[11] Aziz MA, Schoeman SJ, Jordaan GF, El-Chafie OM, Mahdy AT. Genetic and phenotypic variation of some reproductive traits in Egyptian buffalo. South African Journal of Animal Science 2001;31(3): 195-199. https://doi.org/10.4314/sajas.v31i3.3802

[12] Parmar GA, Gupta JP, Pandey DP, Chaudhari JD, Prajapati BM, Sathwara RN, Patel PA. Genetic and non-genetic factors affecting reproduction traits in Mehsana buffaloes. Life Sciences Leaflets 2017; 92: 61-69.

[13] González-Stagnaro C. Parámetros, cálculos e índices aplicados en la evaluación de la eficiencia reproductiva. In: González-Stagnaro C, editor. Reproducción Bovina. Venezuela: Astrodata 2001; p. 203-247.

[14] Qureshi MS, Ahmad N. Interaction of calf suckling, use of oxytocin and milk yield with reproductive performance of dairy buffaloes. Anim Reprod Sci 2008; 106(3-4): 380-392. https://doi.org/10.1016/j.anireprosci.2007.05.019

[15] Kumar PR, Shukla SN, Shrivastava OP, Purkayastha RD. Incidence of postpartum anestrus among buffaloes in and around Jabalpur. Veterinary World 2013; 6(9): 716-719. https://doi.org/10.14202/vetworld.2013.716-719

[16] Sosa ASA, Mahmoud KGhM, Kanddiel MMM, Eldebaky HAA, Nawito MF, Abou El-Roos MEA. Genetic polymorphism of luteinizing hormone receptor gene in relation to fertility of Egyptian buffalo. BioTechnology 2016; 12(5): 1-11.

[17] Nava-Trujillo H, Valeris-Chacin R, Morgado-Osorio A, ValeroGuerra J. Effect of parity and season of calving on the postpartum reproductive activity of water buffalo cows. Zhivotnovadni Nauki (Bulgarian Journal of Animal Husbandry). 2019; 56(4): 3-12.

[18] Nava-Trujillo $H$, Escalona-Muñoz J, Carrillo-Fernández F, Parra-Olivero A. Effect of parity on productive performance and calving interval in water buffaloes. J Buffalo Sci 2018; 7: 13-16.

https://doi.org/10.6000/1927-520X.2018.07.01.3

[19] Nava-Trujillo $H$, Valeris-Chacin R, Quintero-Moreno, A, Escalona-Muñoz J. Milk yield at first lactation, parity, and season of calving affect the reproductive performance of water buffalo cows. Anim Prod Sci 2020; 60(8): 1073-1080. https://doi.org/10.1071/AN18420

[20] Barros CC, Aspilcueta-Borquis RR, Bossi Fraga A, Tonhati $\mathrm{H}$. Genetic parameter estimates for production and reproduction traits in dairy buffaloes. Revista Caatinga 2016; 29(1): 116-221. https://doi.org/10.1590/1983-21252016v29n125rc

[21] Tonhati H, Vasconcellos FB, Albuquerque LG. Genetic aspects of productive and reproductive traits in a Murrah buffalo herd in São Paulo. Brazil. Journal of Animal Breeding and Genetics, Helsinque 2000; 117(5): 331-336.

https://doi.org/10.1046/j.1439-0388.2000.00249.x

[22] Kumar PR, Shukla SN and Purkayastha RD. Economical analysis of the estimated cost of management of anestrus buffaloes under field conditions using different hormonal and non-hormonal strategies. J Anim Health Prod 2013; 1(4): 3941.

[23] Cicek H, Tandoga M, Uyarlar C. Financial losses due to fertility problems in Anatolian dairy buffalo. Indian J Ani Res 2017; 51(6): 1144-1148. https://doi.org/10.18805/ijar.10981

[24] Safari A, Shadparvar AA, Hossein-Zadeh NG, AbdollahiArpanahi R. Economic values and selection indices for production and reproduction traits of Iranian buffaloes (Bubalus bubalis). Trop Anim Health Prod 2019; 51(5): 12091214. https://doi.org/10.1007/s11250-019-01811-7

[25] Sanker S, Kumar D, Mandal KG, Taggar RK, Das AK Factors influencing the dry period and calving interval in different grades of buffaloes. Buffalo Bulletin 2014; 33(1): 120-126.

[26] Kumar TVC, Sharma D, Naidu Surla G, Veerapa Vedamurthy G, Singh D, Kumar Onteru S. Body condition score, parity, shelter cleanliness and male proximity: highly associated non-genetic factors with post-partum anestrus in Murrah buffalo in field conditions. Anim Reprod Sci 2020. https://doi.org/10.1016/j.anireprosci.2020.106282

[27] Christa Charlini B, Sinniah J. Performance of Murrah, Surti, Nili-Ravi buffaloes and their crosses in the intermediate zone of Sri Lanka. Livest Res Rural Dev 2015; 27:Article 47. from http://www.Irrd.org//rrd27/3/char27047.html

[28] Timsina MP, Tamag NB, Rai DB, Siddky MNA. Comparative production and reproduction performances of local and Murrah-cross buffaloes managed by smallholder farmers in Bhutan. SAARC J Agri 2015; 13(1): 200-206. https://doi.org/10.3329/sja.v13i1.24192

[29] Rojas NJ. Comportamiento productivo y reproductivo de búfalas lecheras en un sistema semi-intensivo bajo condiciones de bosque húmedo tropical. Trabajo de Ascenso. Universidad del Zulia. Facultad de Ciencias Veterinarias. Departamento de Producción Animal. Cátedra de Sistemas de Producción de Rumiantes. Maracaibo, Venezuela. 2016; 88 p.

[30] Nasr MAF. The impact of cross-breeding Egyptian and Italian buffalo on reproductive and productive performance under a subtropical environment. Reprod Dom Anim 2016; 52(2): 17.

https://doi.org/10.1111/rda.12881

[31] Nasr MAF. The potential effect of temperature-humidity index on productive and reproductive performance of buffaloes with different genotypes under hot conditions. Environ Sci Pollut Res 2017; 24: 18073-18082.

https://doi.org/10.1007/s11356-017-9450-2

[32] El-Bayomi KM, Saleh AA, Awad A, El-Tarabany MS, ElQaliouby HS, Afifi M, El-Komy S, Essawi WM, Almadaly EA, El-Magd MA. Association of CYP19A1 gene polymorphisms with anoestrus in water buffaloes. Reprod Fertil Dev 2018; 30(3): 487-497. https://doi.org/10.1071/RD16528

[33] Nasr MAF, El Araby IE. Associations of leptin and pituitaryspecific transcription factor genes' polymorphisms with reproduction and production traits in dairy buffalo. Reprod Dom Anim 2016; 51(4). https://doi.org/10.1111/rda.12726

[34] de Camargo GM, Aspilcueta-Borquis RR, Fortes MR, PortoNeto R, Cardoso DF, Santos DJ, Lehnert SA, Reverter A, Moore SS, Tonhati H. Prospecting major genes in dairy buffaloes. BMC Genomics 2015; 16: 872. https://doi.org/10.1186/s12864-015-1986-2 
[35] Li J, Liu J, Campanile G, Plastow G, Zhang C, Wang Z, Cassandro M, Gasparrini B, Salzano A, Hua G, Liang A, Yang L. Novel insights into the genetic basis of buffalo reproductive performance. BMC Genomics 2018; 19(1): 814. https://doi.org/10.1186/s12864-018-5208-6

[36] Verma R, Singh I, Balhara AK, Nayan V, Kumar Sharma R, Chaudhiry V. Correlation between extremes age at first calving with their productive and reproductive performances in Indian Murrah buffaloes (Bubalus bubalis). Indian J Anim Res 2018; 52(10): 1506-1512. https://doi.org/10.18805/ijar.B-3371

[37] Mourits MCM, Huirne RBM, Dijkhuizen AA, Kristensen AR, Galligan DT. Economic optimization of dairy heifers management decisions. Agricultural Systems 1999; 61: 1731.

https://doi.org/10.1016/S0308-521X(99)00029-3

[38] Lin CY, McAllister AJ, Batra TR, Lee AJ, Roy GL, Vesely JA, Wauthy JM, Winter KA. Effects of early and late breeding of heifers on multiple lactation performances of dairy cows. J Dairy Sci 1988; 71: 2735-2743.

https://doi.org/10.3168/jds.S0022-0302(88)79867-7

[39] Zicarelli L. Can we consider buffalo a non-precocious and hypofertile species? Italian J Anim Sci 2007; 6(Suppl 2): 143154.

https://doi.org/10.4081/ijas.2007.s2.143

[40] Sabia E, Napolitano F, De Rosa G, Terzano GM, Barile VL, Braghieri A, Pacelli $C$. Efficiency to reach age of puberty and behavior of buffalo heifers (Bubalus bubalis) kept on pasture or in confinement. Animal 2014; 8(11): 1907-1916. https://doi.org/10.1017/S1751731114001876

[41] Hussein HA, Abdel-Raheem SM. Effect of feed intake restriction on reproductive performance and pregnancy rate in Egyptian buffalo heifers. Trop Anim Health Prod. 2013; 45: 1001-1006.

https://doi.org/10.1007/s11250-012-0324-9

[42] Montiel Urdaneta NS. Algunos aspectos reproductivos e inseminación artificial en búfalas. En: Proceedings $X$ Seminario de Pastos y Forrajes. 2006; Maracaibo, Venezuela; p. 174-186.

[43] Khan S, Qureshi MS, Chand N, Sultan A, Khan RI, Ihsanullah, Tanweer AJ, Sohail SM, Hussain M, Akhtar A, Khan D. Effect of breeding method on calf sex and postpartum reproductive performance of cattle and buffaloes. Sarhad J Agric 2012; 28(3): 469-476.

[44] Kantharaja KJ, Tomar AKS, Nataraju OR, Naveen Kumar BT. Effects of weaning and sex of calf on postpartum resumption of reproduction in mother buffaloes. Int $\mathrm{J}$ Curr Microbiol App Sci 2018; 7(05): 734-737.

https://doi.org/10.20546/ijcmas.2018.705.088

[45] Amjad MA, Lodhi LA, Awais MM, Hassan FU, Ahmad W. Effect of birth weight and sex of the calf on incidence of calving disorders in buffaloes in Punjab province, Pakistan (a case study). Sci.Int.(Lahore) 2016; 28(3): 3179-3182.

[46] El-Fouly MA, Kotby EA, El-Sobhy, AE. Postpartum ovarian activity in suckled and milked buffaloes. Theriogenology 1976; 5: 69-79.

https://doi.org/10.1016/0093-691X(76)90170-9

[47] Rijasnaz VV, Mondal SK, Fahim A. Effect of weaning on the postpartum reproductive performance of Murrah buffaloes. Indian J Anim Res 2014; 48(5): 501-503. https://doi.org/10.5958/0976-0555.2014.00019.3

[48] Perea-Ganchou F, Soto-Belloso E. Uso del destete temporal para mejorar la eficiencia reproductiva en rebaños doble propósito. In: González-Stagnaro, C. y Soto Belloso, E, editors. Desarrollo Sostenible De La Ganadería De Doble Propósito. Venezuela: Fundación Grupo de Investigadores de la Reproducción Animal en la Región Zuliana. 2008; p 570-584.
[49]

Hoffman DP, Stevenson JS, Minton JE. Restricting calf presence without suckling compared with weaning prolongs postpartum anovulation in beef cattle. J Anim Sci 1996; 74(1): 190-198.

https://doi.org/10.2527/1996.741190x

[50] Cady RA, Shah SK, Schermerhorn EC, McDowell RE. Factors affecting performance of Nili-Ravi buffaloes in Pakistan. J Dairy Sci 1983; 66: 578-586. https://doi.org/10.3168/jds.S0022-0302(83)81828-1

[51] Thiruvenkadan AK, Panneerselvam S, Murali N, Selvam S, Ramesh Saravana KV. Milk production and reproduction performance of Murrah buffaloes of Tamil Nadu, India. Buffalo Bulletin 2014; 33: 291-300.

[52] Kumar V. Factors affecting performance of Indian Murrah buffalo: A Review. J Buffalo Sci 2015; 4: 21-27.

[53] Hassan FAM, Ali MA, El-Tarabany MS. Economic impacts of calving season and parity on reproduction and production traits of buffaloes in the sub-tropics. Environ Sci Pollut Res 2017; 24: 10258-10266.

https://doi.org/10.1007/s11356-017-8686-1

[54] El-Tarabany MS. Survival analysis and seasonal patterns of pregnancy outcomes in Egyptian buffaloes. Livest Sci 2018; 213: $61-66$

https://doi.org/10.1016/j.livsci.2018.05.008

[55] Nasr MAF. The effect of stillbirth on reproductive and productive performance of pure Egyptian buffaloes and their crosses with Italian buffaloes. Theriogenology 2017; 103: 916.

https://doi.org/10.1016/j.theriogenology.2017.07.035

[56] Jamuna V, Chakravarty AK. Evaluation of fertility in relation to milk production and productivity of Murrah buffaloes. Anim Reprod Sci 2016; 171: 72-80. https://doi.org/10.1016/j.anireprosci.2016.06.001

[57] Jakhar V, Yadav AS, Dahka SS. Analysis of different non genetic factors on production performance traits in Murrah buffaloes. Inter J Current Microbiol Appl Sci 2017; 6(11): 4265-4272. https://doi.org/10.20546/ijcmas.2017.611.501

[58] Zicarelli L. Reproductive seasonality in buffalo. In: Proceedings of the Third Course on Biotechnology of Reproduction in Buffaloes (Issue II); 1997; p. 29-52.

[59] Vecchio D, Neglia G, Rendina M, Marchiello M, Balestrieri A, Di Palo R. Dietary influence on primiparous and multiparous buffalo fertility. Italian J Anim Sci 2007; 6(Suppl 1): 512-514. https://doi.org/10.4081/ijas.2007.1s.512

[60] Bolívar Vergara DM, Ramírez Toro EJ, Agudelo Gómez DA Angulo Arroyave RA, Cerón Muñoz MF. Parámetros genéticos para características reproductivas en una población de búfalos (Bubalus Bubalis Artiodactyla, Bovidae) en el magdalena medio colombiano. Rev Fac Nac Agron 2010; 63: 5587-5594.

[61] Araujo Berber RC, Madureira EH, Baruselli PS. Comparison of two Ovsynch protocols (GnRH vs LH) for fixed timed insemination in buffalo (Bubalus bubalis). Theriogenology 2002; 57: 1421-1430.

https://doi.org/10.1016/S0093-691X(02)00639-8

[62] Naqvi AN. Effect of parity and season of calving on service period in Nili Ravi buffalo in Pakistan. Asian-Autralas $\mathrm{J}$ Anim Sci 2000; 13: 287-291.

[63] Barile VL. Improving reproductive efficiency in female buffaloes. Liv Prod Sci 2005; 92(3): 183-194. https://doi.org/10.1016/j.livprodsci.2004.06.014

[64] Zicarelli L. Enhancing reproductive performance in domestic dairy water buffalo (Bubalus bubalis). Soc Reprod Fertil Suppl 2010; 67: 443-455.

[65] Gasparrini B. Effect of reproductive season on embryo development in the buffalo. Reprod Fert Dev 2019; 31: 6881.

https://doi.org/10.1071/RD18315 
[66] Nava-Trujillo $H$, Valeris-Chacin $R$, Hernandez J, Duran Nuñez M, Morgado-Osorio A, Caamaño J, Quintero-Moreno A. Effect of season and parity on water buffalo calving distribution throughout the year in Venezuela. Rev Acad Ciênc Anim 2019; 17: e17013. https://doi.org/10.7213/1981-4178.2019.17013

[67] Rossi P, Vecchio D, Neglia G, Di Palo R, Gasparrini B, D'Occhio R, Campanile G. Seasonal fluctuations in the response of Italian Mediterranean buffaloes to synchronization of ovulation and timed artificial insemination. Theriogenology 2014; 82(1): 132-137. https://doi.org/10.1016/j.theriogenology.2014.03.005

[68] Saraswat CS, Purohit GN. Repeat breeding: Incidence, risk factors and diagnosis in buffaloes. Asian Pac J Reprod 2016; 5(2): 87-95.

https://doi.org/10.1016/j.apjr.2016.01.001

[69] Di Francesco S, Neglia G, Vecchio D, Rossi P, Russo M, Zicarelli L, D'Occhio MJ, Campanile G. Influence of season on corpus luteum structure and function and $\mathrm{Al}$ outcome in the Italian Mediterranean buffalo (Bubalus bubalis). Theriogenology 2012; 78: 1839-1845. https://doi.org/10.1016/j.theriogenology.2012.07.022

[70] Zoheir KMA, Abdoon AS, Mahrous KF, Amer MA, Zaher MM, Li-Guo Y, El-Nahass EM. Effects of season on the quality and in vitro maturation rate of Egyptian Buffalo (Bubalus bubalis) oocytes. J Cell Anim Biology 2007; 1:29-33.

[71] El-Naby AAHH, Mahmoud KGHM, Ahmed YF, Abouel-Roos MEA, Abdel-Ghaffar AE. Effect of season of the year and ovarian structures on oocytes recovery rate, quality and meiotic competence in Egyptian buffaloes. Global Veterinaria 2013; 10(4): 408-412.

https://doi.org/10.5829/idosi.gv.2013.10.4.7281

[72] Dharap A. Effect of season on pregnancy rates, milk progesterone, and milk melatonin profiles in water buffalo reared in Canada. Master Thesis. The University of Guelph. Guelph, Ontario, Canada. 2016; 94 pp.

[73] Qayyum A, Arshad U, Yousuf MR, Ahmad N. Effect of breeding method and season on pregnancy rate and embryonic and fetal losses in lactating Nili-Ravi buffaloes. Trop Anim Health Prod 2018; 50: 555-560. https://doi.org/10.1007/s11250-017-1468-4

[74] Roy AK, Singh M, Kumar P, Bharath, Kumar BS. Effect of extended photoperiod during winter on growth and onset of puberty in Murrah buffalo heifers. Veterinary World. 2007; 9(2): 216-221.

https://doi.org/10.14202/vetworld.2016.216-221

[75] Mondal S, Prakash BS, Palta P. Endocrine aspects of oestrous cycle in buffaloes (Bubalus bubalis): an overview. Asian-Australas J Anim Sci 2007; 20(1): 124-131.

[76] Campanile G, Neglia G, Gasparrini B, Galiero G, Prandi A, Di Palo R, Michael JD, Zicarelli L. Embryonic mortality in buffaloes synchronized and mated by Al during the seasonal decline in reproductive function. Theriogenology 2005; 63(8): 2334-2340. https://doi.org/10.1016/j.theriogenology.2004.10.012

[77] Russo M, Vecchio D, Neglia G, Pacelli C, Prandi A, Gasparrini B, Zicarelli L, D'Occhio MJ, Campanile G. Corpus luteum function and pregnancy outcome in buffaloes during the transition period from breeding to non-breeding season. Reprod Dom Anim 2010; 45: 988-991. https://doi.org/10.1111/j.1439-0531.2009.01472.x

[78] Balestrieri ML, Gasparrini B, Neglia G, Vecchio D, Strazzullo M, Giovane A, Servillo L, Zicarelli L, D'Occhio MJ, Campanile G. Proteomic profiles of the embryonic chorioamnion and uterine caruncles in buffaloes (Bubalus bubalis) with normal and retarded embryonic development. Biol Reprod 2013; 88(5): 119 https://doi.org/10.1095/biolreprod.113.108696

[79] Neglia G, Vecchio D, Di Palo R, Pacelli C, Comin C, Gasparrini B, Campanile G. Efficacy of PGF2 $\alpha$ on pre- ovulatory follicle and corpus luteum blood flow. Reprod Dom Anim 2012; 47: 26-31.

https://doi.org/10.1111/j.1439-0531.2011.01794.x

[80] Salzano A, Spagnuolo MS, Lombardi P, Vecchio D, Limone A, Censi SB, Balestrieri A, Pelagalli A, Neglia G. Influences of different space allowance on reproductive performances in buffalo. Anim Reprod 2017; 14(2): 429-436. http://dx.doi.org/10.21451/1984-3143-AR799

[81] Dash S, Chakravarty AK, Sah V, Jamuna V, Behera R, Kashyap N, Deshmukh B. Influence of temperature and humidity on pregnancy rate of Murrah buffaloes under subtropical climate. Asian-Australas J Anim Sci 2015; 28(7): 943-950.

https://doi.org/10.5713/ajas.14.0825

[82] Abdalla EB. Improving the reproductive performance of Egyptian buffalo cows by changing the management system. Anim Reprod Sci 2003; 75: 1-8. https://doi.org/10.1016/S0378-4320(02)-00225-7

[83] Zicarelli L, Esposito L, Campanile G, Di Palo R, Armstrong DT. Effects of using vasectomized bulls in artificial insemination practice on the reproductive efficiency of Italian buffalo cows. Anim Reprod Sci. 1997; 47(3): 171-80. https://doi.org/10.1016/S0378-4320(97)00008-0

[84] Gokuldas PP, Yadav MC, Kumar H, Singh G, Mahmood S Tomar AK. Resumption of ovarian cyclicity and fertility response in bull-exposed postpartum buffaloes. Anim Reprod Sci 2010; 121(3-4): 236-41. https://doi.org/10.1016/j.anireprosci.2010.06.005

[85] Akhtar MS, Irum S, Lashari MH, Ahmad E, Ahmad T, Ayaz MM, Lodhi LA, Ahmad I, Akhtar M: Bio-stimulatory effect of bull on post-partum estrus interval in Nili-Ravi buffaloes. Kafkas Univ Vet Fak Derg 2018; 24(4): 603-606. https://doi.org/10.9775/kvfd.2018.19435

[86] Zaidi NS, Anwar M. Effect of biostimulation on estrus expression, resumption of ovarian activity and conception rate in postpartum anestrus Nili-Ravi buffaloes during low breeding season. Pakistan Vet J 2018; 38(1): 35-38. https://doi.org/10.29261/pakvetj/2018.007

[87] Perumal P, Srivastava N, Srivastava SK, Chamuah JK, Veeraselvam M. Hereditary and congenital causes of infertility in buffalo (Bubalus Bubalis) bulls. IJBSM 2012; 3(4): 472-480.

[88] Perumal P, Kumar TK, Srivastava SK. Infectious causes of infertility in buffalo bull (Bubalus bubalis). Buffalo Bulletin 2013; 32(2): 71-96. https://doi.org/10.14456/ku-bufbu.2013.12

[89] Perumal P, Purohit GN, Balamurugan TC, Prakash Krupakaran R, Veeraselvam M. Infertility in buffalo bulls. In: Bubaline Theriogenology, Purohit G.N. (Ed.). International Veterinary Information Service, Ithaca NY. A5728.0816, 2016. https://www.ivis.org/advances/purohit/chap28/chapter. asp? LA=1

[90] Santos AX, Kahwage PR, Faturi C, Laurenço Junior J, Medina Álvarez WF, Garcia RA. Efecto de la suplementación alimenticia con fuentes lipídicas sobre la ganancia de peso y niveles de testosterona sérica en toros bufalinos. J Vet Andrology 2017; 2(2): 52-59.

[91] Swelum AAZ, Saadeldin IM, Zaher HA, Alsharifi SAM, Alowaimer AN. Effect of sexual excitation on testosterone and nitric oxide levels of water buffalo bulls (Bubalus bubalis) with different categories of sexual behavior and their correlation with each other. Anim Reprod Sci 2017; 181: 151158.

https://doi.org/10.1016/j.anireprosci.2017.04.003

[92] Younis M, Samad HA, Ahmad N, Ahmad I. Effects of age and season on the body weight, scrotal circumference and libido of Nili-Ravi buffalo bulls maintained at the semen production unit, Qadirabad. Pakistan Vet J 2003; 23(2): 5965. 
[93] Younis M, Samad HA, Ahmad N, Ali CS. Effect of age and breeding season on the freezability of buffalo bull semen. Pakistan Vet J 1998; 18(4): 219-223.

[94] Ahmed S, Khan MIR, Ahmad M, Iqbal S. Effect of age on lipid peroxidation of fresh and frozen-thawed semen of NiliRavi buffalo bulls. Italian J Anim Sci 2018; 17(3): 730-735. https://doi.org/10.1080/1828051X.2018.1424569

[95] Garcia AR, Santos AX, Nahúm BS, Silva LKX, Lourenço Junior JB, Joele MRSP. Correlations between consumption, corporal and seminal features of water buffaloes (Bubalus bubalis). Anim Reprod 2012; 9(4): 1028.

[96] Kumar S, Srivastava S. Testicular biometry and its correlation with body weight and semen output in Murrah bull. Buffalo Bulletin 2017; 36(1): 105-113.

[97] Yadav KS, Singh P, Bhakat M, Mohanty KT, Kumar A, Singh A, Mondal S, Upadhyay VK, Tomar S. Relationship of age, body condition score and rump fat thickness with semen quality in Murrah buffalo breeding bulls. Int $\mathrm{J}$ Livest Res 2018; 8(8): 110-120.

https://doi.org/10.5455/ijlr.2018011601554

[98] Singh K, Kumar A, Honparkhe M, Dadarwal D. Ultrasonographic approaches for breeding soundness evaluation of high and low libido buffalo bulls. Indian J Anim Sci 2015; 85(5): 451-453.

[99] Henry M, Brito MF, Neves BP, Auler PA, Almeida J, Andrade GO, Becerra VB, Bergmann L. Peculiarities of the buffalo species for andrological evaluation - results of four years of study and weekly semen collection schedule. Anim Reprod 2017; 14(Suppl.1): 1225-1233.

https://doi.org/10.21451/1984-3143-AR0005

[100] Napolitano F, Pacelli C, Grasso F, Braghieri A, De Rosa G. The behaviour and welfare of buffaloes (Bubalus bubalis) in modern dairy enterprises. Animal 2013; 7(10): 1704-1713. https://doi.org/10.1017/S1751731113001109

[101] El-Belely NS, Zaky K, Grunert E. Plasma profiles of progesterone and total estrogens in buffaloes (Bubalus bubalis). J Agric Sci Cambridge 1988; 111: 519-524. https://doi.org/10.1017/S0021859600083726

[102] El-Fadaly MA. Effect of suckling and milking on breeding efficiency of buffaloes. II. First postpartum estrus. Vet Med J Egypt 1980; 28: 399-404.

[103] El-Azab EA, Mansour H, Heshmat H, Shawki G. The postpartum period and future fertility of the Egyptian buffalo cows. In: Proceedings of the 10th Int. Congr. Animal. Reprod. \& A.I., vol. III, Urbana, 1984; p. 424

[104] Valsalan J, Chakravarty AK, Patil CS, Dash SK, Mahajan AC, Kumar V, Vohra V. Enhancing milk and fertility performances using selection index developed for Indian Murrah buffaloes. Trop Anim Health Prod 2014; 46: 967-74. https://doi.org/10.1007/s11250-014-0596-3

[105] Seno LO, Cardoso VL, El Faro L, Sasana RC, AspilcuetaBorquis RR, De Camargo GMF, Tonhati H. Genetic parameters for milk yield, age at first calving and interval between first and second calving in milk Murrah buffaloes. Liv Res Rural Dev 2010; 22: Article \#38 http://www.Irrd.org//rrd22/2/seno22038.htm

[106] El-Keraby F, Aboul-Ela, MB, Bedeir LH. The effect of diet on postpartum reproductive traits in buffaloes. Agric Res Rev 1981; 59: 1-12.

[107] Kawthar AM, Youssif RH, Khattab AS. Individual factors affecting the interval between calving and first service in Egyptian buffaloes. Egypt J Anim Prod 1985; 25: 319-327.

[108] Singh N, Chauhan FS, Singh M. Postpartum ovarian activity and fertility in buffaloes. Indian J Diary Sci 1979; 32: 134139.

[109] Suthar BN, Kavan FS. Occurrence and nature of first postpartum estrus in Mehsani buffaloes. Indian J Anim Reprod 1992; 13: 161-164.
[110] Vilela RNS, Sena TM, Aspilcueta-Borquis RR, Seno LO, De Araujo Neto FR, Becker Scalez DC, Tonhati H. Genetic correlations and trends for traits of economic importance in dairy buffalo. Anim Prod Sci 2020; 60(4): 492-496. https://doi.org/10.1071/AN19051

[111] Borghese A, Rasmussen M, Thomas CS. Milking management of dairy buffalo. Italian J Anim Sci 2007; 6(Sup 2): $39-50$.

https://doi.org/10.4081/ijas.2007.s2.39

[112] Akhtar MS, Lodhi LA, Farooq AA, Ayaz MM, Hussain M, Lashari $\mathrm{MH}$, Chaudhary Zl. Effect of oxytocin administration before milking on milk production, somatic cells count and fat contents in milk of NiliRavi buffaloes. Pakistan Vet J 2012; 32(3): 435-437.

[113] Iqbal Z, Rahman ZU, Muhammad F, Khaliq T, Anwar H, Awais MM, Sadaf $S$. Oxytocin induced oxidative stress in lactating Bubalis (Nili-Ravi). BMC Vet Res 2013; 9(1): 169.

[114] Mustafa MY, Saleem K, Munir R, Butt TM. Effect of oxytocin on the productive and reproductive performance of buffalo and cattle in Sheikhupura-Pakistan (A field study). Livest Res Rural Dev 20(12): 193. http://www.Irrd.org//rrd20/12/must20193.htm

[115] Baruselli PS, Barnabe VH, Barnabe RC, Visintin JA, MoleroFilho JR, Porto Filho R. Effect of body condition score at calving on postpartum reproductive performances in buffalo. Buff J. 2001; 1: 53-65.

[116] Mahmoud ME, Salman D. Low body condition scoring as a detrimental factor to reproductive performance and behavior in dairy cattle and Seidi buffaloes. Assiut Vet Med J 2015; 61(145): 112-118.

[117] Bhalaru S, Tiwana MS, Singh N. Effect of body condition at calving, on subsequent reproductive performance in buffaloes. Indian J Anim Sci 1987; 57: 33-36.

[118] Patel M, Lakhani GP, Ghosh S, Nayak S, Roy B, Baghel RPS, Jain A. Effect of body condition score on milk production, milk composition and reproductive performance of lactating Murrah buffaloes. Int J Curr Microbiol App Sci 2018; 7(11): 1204-1212.

https://doi.org/10.20546/ijcmas.2018.711.140

[119] Othoman OE, Ahmed WM, Balabel EA. Genetic polymorphism of Cyp19 gene and its association with ovarian activity in Egyptian buffaloes. Global Veterinaria 2014; 12(6): 768-773.

https://doi.org/10.5829/idosi.gv.2014.12.06.83270

[120] Gamit PM, Singh RR, Kumar A, Kharadi VB, Patel NB. Relationship of postpartum interval to estrus, body condition score, milk yield and blood biochemical parameters in Surti buffaloes (Bubalus bubalis). J Applied Nat Sci 2016; 8(2): 899-904.

https://doi.org/10.31018/jans.v8i2.894

[121] Raj MP, Venkata Naidu G, Srinivas M, Raghunath M, Rao KA. Relationship of body condition score at estrus and conception rate in graded Murrah buffaloes. J Anim Res 2016; 6(5): 829-834.

https://doi.org/10.5958/2277-940X.2016.00105.4

[122] Devkota B. Association of nutritional status to reproductive performance in buffaloes. J Agric Forest University 2018; 2: 1-7.

[123] Devkota B, Nakao T, Kobayashi K, Sato H, Sah SK, Singh DK, Dhakal IP, Yamagishi N. Effects of treatment for anestrus in water buffaloes with PGF2 $\alpha$ and $\mathrm{GnRH}$ in comparison with vitamin-mineral supplement, and some factors influencing treatment effects. J Vet Med Sci 2013; 75(12): 1623-1627. https://doi.org/10.1292/jvms.12-0515

[124] Campanile G. Relationship between Nutrition and Reproduction in buffalo. "Third course on biotechnology of reproduction in buffaloes". Bubalus bubalis 1997; 4(Suppl 1): 217-235. 
[125] Abayawansa WD, Prabhakar S, Singh AK, Brar PS. Bodyweight changes in winter and summer calving buffalo during peripartum period. Indian J Anim Reprod 2012; 33(2): 47-50.

[126] Deka RS, Mani V, Kumar M, Shiwajirao ZS, Tyagy AK, Kaur $\mathrm{H}$. Body condition, energy balance and immune status of periparturient Murrah buffaloes (Bubalus bubalis) supplemented with inorganic chromium. Biol Trace Elem Res 2014; 161: 57-68.

https://doi.org/10.1007/s12011-014-0069-6

[127] Reddy NA, Venkata Seshiah $\mathrm{CH}$, Sudhakar K, Srinivasa Kumar D, Kanth Reddy PR. Negative energy balance indicators as predictors for milk production in high yielding Murrah buffaloes. GJBB 2017; 6(2): 369-373.

[128] Delfino NC, Bulcão LFA, Alba HDR, Oliveira MXDS, Queiroz FPS, Carvalho GGP, Rennó FP, de Freitas Júnior JE. Influence of body condition score at calving on the metabolic status and production performance of Murrah buffaloes (Bubalus bubalis) during the transition period. AsianAustralas J Anim Sci 2018; 31(11): 1756-1765. https://doi.org/10.5713/ajas.17.0223

[129] Fiore E, Giambelluca S, Morgante M, Contiero B, Mazzotta E, Vecchio D, Vazzana I, Rossi P, Arfuso F, Piccione G, Gianesella M. Changes in some blood parameters, milk composition and yield of buffaloes (Bubalus bubalis) during the transition period. Anim Sci J 2017; 88(12): 2025-2032. https://doi.org/10.1111/asj.12872

[130] Fiore E, Arfuso F, Gianesella M, Vecchio D, Morgante M, Mazzotta E, Badon T, Rossi P, Bedin S, Piccione G. Metabolic and hormonal adaptation in Bubalus bubalis around calving and early lactation. PLoS One 2018; 13(4): e0193803. https://doi.org/10.1371/journal.pone.0193803

[131] Bhalaru S, Dhillon J, Tiwana M. Effect of body weight at calving on body-weight changes during early lactation and post-partum reproductive performance in buffaloes. The Journal of Agricultural Science 1981; 97(3): 595-597. https://doi.org/10.1017/S0021859600036923

[132] Infascelli F, De Rosa C, Amante L, Zicarelli F, Potena A, Campanile G. Productive level and energy balance in buffalo cow. Italian J Anim Sci 2003; 2(Suppl. 1): 204-206.

[133] Jalali MT, Nouri M, Rasooli A, Haji Hajikolaei MR, Shahryari A, Shirazi MR. Hepatic triacylglycerols and serum nonesterified fatty acids (NEFA) variations in indigenous water buffalo (Bubalus bubalis) in the province of Khuzestan, Iran. Int J Vet Res 2011; 5(3): 151-155.

[134] Monteiro BM, Yasouka MM, Pogliani FC, Ayres H, Viana RB, Birgel Junior EH. Lipid and glucose profiles of dairy buffaloes during lactation and dry period. Rev Cienc Agrar 2012; 55(1): 33-39.

https://doi.org/10.4322/rca.2012.034

[135] Verdurico LC, Gandra JR, Tekiya CS, Freitas Junior JE, Barletta RV, Gardinal R, Calomeni GD, De Paiva PG, Renno FP. Differences in blood and milk fatty acid profile of primiparous and multiparous Mediterranean buffaloes cows during transition period and early lactation. J Buffalo Sci 2015; 4(2): 40-45

[136] Pande N, Agrawal R, Shrivastava OP, Swamy M. Alterations in haemato-metabolic status and body condition score of buffaloes during the transition period. J Livestock Sci 2016; 7: $122-125$.

[137] Ahmed EA, Elsayed DH, Kilani OE, El-Beltagy MA. Multivitamins preventive therapy against subclinical endometritis in buffaloes: Its correlation to NEFA and oxidative stress. Reprod Biology 2017; 17(3): 239-245 https://doi.org/10.1016/j.repbio.2017.05.008

[138] Reddy NA, Venkata Seshiah $\mathrm{CH}$, Sudhakar K, Srinivasa Kumar D, Kanth Reddy PR. Extent of adaptation of high yielding murrah buffaloes to negative energy balance in response to various dry period lengths. Indian J Anim Res 2018; 52(11): 552-1556.

https://doi.org/10.18805/ijar.B-3407

[139] Golla N, Chopra A, Boya S, Kumar TVC, Onteru SK, Singh D. High serum free fatty acids and low leptin levels: Plausible metabolic indicators of negative energy balance in early lactating Murrah buffaloes. J Cell Physiol 2019; 234(6): 77257733.

https://doi.org/10.1002/jcp.28081

[140] Campanile G, Di Palo R, Zicarelli L. Bilancio energetico e attività riproduttiva nella specie bufalina. Proc. I Congr. Naz. sull'All. del Bufalo, Eboli (SA); 2001. P. 114-127

[141] Mavi PS, Bahga, CS, Verma HK, Uppal SK, Sidhu SS. 2011. Postpartum performance as influenced by body weight changes at parturition in buffaloes. Indian J Anim Reprod 2011; 32(1): 61-63.

[142] Huseein HA, Senosy W, Abdellah MR. Relationship among uterine involution, ovarian activity, blood metabolites and subsequent reproductive performance in Egyptian buffaloes. Open J Animal Sci 2013; 3(1): 59-69. https://doi.org/10.4236/ojas.2013.31009

[143] Banu TA, Shamsuddin M, Bhattacharjee J, Islam MF, Khan SI, Ahmed JU. Milk progesterone enzyme-linked immunosorbent assay as a tool to investigate ovarian cyclicity of water buffaloes in relation to body condition score and milk production. Acta Vet Scand 2012; 54: 30. https://doi.org/10.1186/1751-0147-54-30

[144] Senosy W, Hussein HA. Association among energy status, subclinical endometritis postpartum and subsequent reproductive performance in Egyptian buffaloes. Anim Reprod Sci 2013; 140: 40-46. https://doi.org/10.1016/j.anireprosci.2013.05.004

[145] Elsayed DH, Abdelrazek HMA, El Nabtiti AAS, Mahmoud YK, Abd El-Hameed NE. Associations between metabolic profiles, post-partum delayed resumption of ovarian function and reproductive performance in Egyptian buffalo: Functions of IGF-1 and antioxidants. Anim Reprod Sci 2019; 208: 106134. https://doi.org/10.1016/j.anireprosci.2019.106134

[146] Zulu VC, Sawamukai Y, Nakada K, Kida K, Moriyoshi M. Relationship among insulin-like growth factor-I, blood metabolites and postpartum ovarian function in dairy cows. $J$ Vet Med Sci 2002; 64(10): 879-85.

[147] Butler ST, Marr AL, Pelton SH, Radcliff RP, Lucy MC, Butler WR. Insulin restores $\mathrm{GH}$ responsiveness during lactationinduced negative energy balance in dairy cattle: effects on expression of IGF-I and GH receptor 1A. J Endocrinol 2003; 176: 205-217.

[148] Mili B, Pandita S, Bharath Kumar BS. Association of blood metabolites with reproductive disorders in postpartum Murrah buffaloes. Buffalo Bulletin 2016; 35(4): 643-651.

[149] Patra MK, Kumar H, Nandi S. Neutrophil functions and cytokines expression profile in buffaloes with impending postpartum reproductive disorders. Asian Australas J Anim Sci 2013; 26(10): 1406-1415. https://doi.org/10.5713/ajas.2012.12703

[150] Esposito G, Iron PC, Webb EC, Chapwanya A. Interactions between negative energy balance, metabolic diseases, uterine health and immune response in transition dairy cows. Anim Reprod Sci 2014; 144: 60-71. https://doi.org/10.1016/j.anireprosci.2013.11.007

[151] Qureshi MS, Habib G, Samad HA, Siddiqui MM, Ahmad N, Syed M. Reproduction-nutrition relationship in dairy buffaloes. I. Effect of intake of protein, energy and blood metabolites levels. Asian-Australas J Anim Sci 2002; 15: 330-339

[152] Ahmed WM, El Khadrawy HH, Hanafi EM, El Hameed ARA, Sabra HA. Effect of copper deficiency on ovarian activity in Egyptian buffalo-cows. World J Zoology 2009; 4(1): 01-08. 
[153] Hafez MH. Serum hormonal, metabolic and minerals profile in normal cyclic and postpartum anestrus Egyptian buffaloes. AJVS 2019; 60(2): 102-108. https://doi.org/10.5455/ajvs. 27345

[154] Dhami AJ, Thavani KL, Patel JA, Sarvaiya NP. Post-abortion and post-partum serum progesterone profile and breeding efficiency in buffaloes retaining fetal membranes. Buffalo Bulletin 2012; 31(4): 189-192.

[155] Khan HM, Mohanty TK, Raina VS, Gupta AK, Bhakat M. Effect of peripartum disorders on reproduction performance traits in Murrah buffaloes at an organized farm. Buffalo Bulletin 2009; 28(4): 176-211.

[156] Jan MH, Kumar H, Sharma RK, Kumar S, Gupta A. Prevalence, risk factors and impact of subclinical endometritis on reproductive performance of Nili-Ravi buffalo. J Anim Res 2019; 9(2): 351-357. https://doi.org/10.30954/2277-940X.02.2019.21

[157] Thu LT, My LR, Lan PD, Lang PS, Phuc DV, Doanhi PQ. Epidemiological survey on Trypanosoma evansi infection in Vietnam. J Protozool Res 1998; 8: 177-181.

[158] Fagiolo A, Roncoroni C, Lai O, Borghese A. Buffalo pathologies. In: Antonio Borghese, editor. Buffalo Production and Research 2005; p. 249-296.

[159] Galiero G. Causes of infectious abortion in the Mediterranean buffalo. Italian J Anim Sci 2007; 6(Suppl 2): 194-199. https://doi.org/10.4081/ijas.2007.s2.194

[160] Martuccello A, di Mia GM, Giammarioli M, De Donato I, lovane G, Galiero G. Detection of Bovine viral diarrhea virus from three water buffalo fetuses (Bubalus bubalis) in southern Italy. J Vet Diagn Invest 2009; 21: 137-140. https://doi.org/10.1177/104063870902100123

[161] Paradiso R, Riccardi MG, Lucibelli MG, Cerrone A, Amelio T, Del Piano F, De Carlo E, Galiero G, Borriello G. Novel approaches for diagnosis of bacterial agents responsible for abortion in water buffalo through metagenomic análisis. Memories 11th WORLD BUFFALO CONGRESS 2016, Colombia 23-26 November, 2016. In: CES Medicina Veterinaria y Zootecnia. Septiembre-Diciembre: 224.

[162] Pérez-Gil R. Identificación molecular de Leptospira spp. patógenas en cultivos provenientes de fetos bovinos abortados. Memories 11th WORLD BUFFALO CONGRESS 2016, Colombia 23-26 November, 2016. In: CES Medicina Veterinaria y Zootecnia. Septiembre-Diciembre: 229.

[163] Shaapan RM. The common zoonotic protozoal diseases causing abortion. J Parasit Dis 2016; 40(4): 1116-1129. https://doi.org/10.1007/s12639-015-0661-5

[164] Maherchandani S, Kumar A, Kashyap SK. Infectious causes of bufaline abortion. In: Bubaline Theriogenology, Purohit G.N. (Ed.). International Veterinary Information Service, Ithaca NY. 2018; A5711.0715. https://www.ivis.org/advances/ purohit/chap10/chapter.asp?LA=1

[165] Saini P, Singh M, Kumar P. Fungal endometritis in bovines. Open Vet J. 2019; 9(1): 94-98. doi: 10.4314/ovj.v9i1.16.

[166] Ciuca L, Borriello G, Bosco A, D’Andea L, Gringoli G, Ciaramella P, Maurelli MP, Di Loria A, Rinaldi L, Guccioni J. Seroprevalence and clinical outcomes of Neospora caninum, Toxoplasma gondii and Besnoitia besnoiti infections in water buffaloes (Bubalus bubalis). Animals 2020; 10(3): 532. https://doi.org/10.3390/ani10030532

[167] Kumar A, Kumar S, Singh M, Gokuldas PP, Kumar P. Noninfectious Causes of Bubaline Abortions. In: Bubaline Theriogenology, Purohit G.N. (Ed.). International Veterinary Information Service, Ithaca NY. 2015;A5711.0715 https://www.ivis.org/advances/purohit/chap11/chapter.asp?L $\mathrm{A}=1$

[168] Ijaz M, Ghaffar A, Ali A, Farooqi SH, Khan YR, Aqib Al. Seroprevalence of leptospirosis and its association with reproductive and productive parameters from buffalo population of Rajanpur and Muzaffargarh districts of Pakistan. J Anim Plant Sci 2020; 30(1): 58-64.

[169] Roncoroni C, Barile VL, Allegrini S, Grifoni G, Pettirossi N, Fagiolo A. Serological survey and reproductive performances in buffaloes under fixed time artificial insemination. Italian $\mathrm{J}$ Anim Sci 2007; 6(Suppl 2): 828-831. https://doi.org/10.4081/ijas.2007.s2.828

[170] Ahmed WM, Zaher KS. A field contribution of the relation between reproductive disorders and bovine viral diarrhea virus infection in buffalo-cows. American-Eurasian J Agric Environ Sci 2008; 3(5): 736-742.

[171] Manimaran A, Kumaresan A, Sreela L, Boopathi V, Arul Prakash M. Effects of clinical mastitis on days open in dairy cattle and buffaloes. Indian Vet J 2014; 91(12): 67-8.

[172] Mansour MM, Zeitoun MM, Hussein FM. Mastitis outcomes on pre-ovulatory follicle diameter, estradiol concentrations, subsequent luteal profiles and conception rate in Buffaloes. Anim Reprod Sci 2017; 181: 159-166

https://doi.org/10.1016/j.anireprosci.2017.04.004

[173] Mansour MM, Hendawy AO, Zeitoun MM. Effect of mastitis on luteal function and pregnancy rates in buffaloes. Theriogenology 2016; 86(5): 1189-94. https://doi.org/10.1016/j.theriogenology.2016.04.009

[174] Bifulco G, Veneziano V, Cimmino R, Esposito L, Auletta L, Varricchio E, Balestrieri A, Claps S, Campanile G, Neglia G. Effect of pour-on alphacypermethrin on feed intake, body condition score, milk yield, pregnancy rates, and calving-toconception interval in buffaloes. J Anim Sci 2015; 93(4): 1850-1858.

https://doi.org/10.2527/jas.2014-8352

[175] Ahmed WM, Habeeb SM, El Moghazy FM, Hanafi EM. 2009. Observation on pediculosis in buffalo-cows with emphasis on its impact on ovarian activity and control by herbal remedies. WASJ 2009; 6(8): 1128-1138.

[176] El-Khadrawy HH, El Moghazy FM, El Aziz MMA, Ahmed WM. Field investigation on the correlation between ovarian activity and fascioliosis in buffalo-cows. American-Eurasian J. Agric. \& Environ. Sci. 2008; 3(4): 539-546.

[177] Vale WG, Ribeiro HFL. Caracteristicas reprodutivas dos bubalinos: puberdade, ciclo estral, involuaçào uterina $e$ atividade ovariana no pós-parto. Rev Bras Reprod Anim 2005; 29: 63-73.

[178] Rahman MS, Shohag AS, Kamal MM, Parveen N, Shamsuddin, M. Application of ultrasonography to investigate postpartum anestrus in water buffaloes. Reprod Dev Biol 2012; 36(2): 103-108.

[179] Perera BM. Reproductive cycles of buffalo. Anim Reprod Sci 2011; 124(3-4): 194-199. https://doi.org/10.1016/j.anireprosci.2010.08.022

[180] Campanile G, Baruselli PS, Vecchio D, Prandi A, Neglia G Carvalho NAT, Sales JNS, Gasparrini B, D'Occhio MJ. Growth, metabolic status and ovarian function in buffalo (Bubalus bubalis) heifers fed a low energy or high energy diet. Anim Reprod Sci 2010; 122(1-2): 74-81. https://doi.org/10.1016/j.anireprosci.2010.07.005

[181] Singh G, Adams G. The reproductive pattern and efficiency of female buffaloes. Anim Reprod Sci 2000; 60-61: 593-604. https://doi.org/10.1016/S0378-4320(00)00109-3

[182] Sánchez Valencia J. Aspectos reproductivos y endocrinos del ciclo estral de la hembra bufalina (Bubalus bubalis). Tesis Doctoral, Universidad de Caldas, Colombia, 2016; p.140.

[183] Moioli BM, Napolitano F, Puppo S, Barile VL, Terzano GM, Borghese A, Malfatti A, Catalano A, Pilla AM. Patterns of oestrus, time of $\mathrm{LH}$ release and ovulation and effects of time of artificial insemination in Mediterranean buffalo cows. Anim. Sci 1998; 66: 87-91. https://doi.org/10.1017/S1357729800008869 
[184] Baruselli PS, Carvalho NAT. Reproduction Management and artificial insemination in buffalo. In: $1^{\text {st }}$ Buffalo Symposium of Americas, Belém, PA. Proceedings 2002; p.119-143.

[185] Barile V.L. Improving reproductive efficiency in female buffaloes. Livest. Prod. Sci. 2005; 92: 183-194. https://doi.org/10.1016/j.livprodsci.2004.06.014

[186] Lohan IS, Malik RK, Kaker ML. Uterine involution and ovarian follicular growth during early postpartum period of Murrah buffaloes (Bubalus bubalis). Asian-Aust. J. Anim. Sci. 2004; 17(3): 313-316

[187] Awasthi MK, Kavani FS, Siddiquee GM, Sarvaiya NP, Derashri HJ. Is slow follicular growth the cause of silent estrus in water buffaloes? Anim Reprod Sci 2006; 99(3-4): 258-68.

https://doi.org/10.1016/j.anireprosci.2006.05.014

[188] Jha SS. Ovarian responses of buffalo treated with PGF2 alpha. Asian Journal of Biochemical and Pharmaceutical Research. 2011; 4: 377-379.

[189] Porto-Filho RM, Gimenes LU, Monteiro BM, Carvalho NAT, Ghuman SPS, Madureira EH, Baruselli PS. Detection of estrous behavior in buffalo heifers by radiotelemetry following PGF2 $\alpha$ administration during the early or late luteal phase. Anim. Reprod. Sci. 2014; 144: 90-94. https://doi.org/10.1016/j.anireprosci.2013.12.006

[190] Hiremath S, Ramesha KP. Controlled breeding and reproductive management in water buffaloes (Bubalus bubalis) using Eazi Breed controlled internal drug release. Journal of the South African Veterinary Association 2015; 86(1): Art. 1064.

https://doi.org/10.4102/jsava.v86i1.1064

[191] Riaz U, Hassan M, Husnain A, Naveed MI, Singh J, Ahmad $\mathrm{N}$. Effect of timing of artificial insemination in relation to onset of standing estrus on pregnancy per $\mathrm{Al}$ in Nili-Ravi buffalo. Anim Reprod 2018; 15(4): 1231-1235. https://doi.org/10.21451/1984-3143-AR2017-0015

[192] Pandey AK, Dhaliwal GS, Ghuman SPS, Agarwal SK. Impact of pre-ovulatory follicle diameter on plasma estradiol, subsequent luteal profiles and conception rate in buffalo (Bubalus bubalis). Anim. Reprod. Sci. 2011; 123: 169-174. https://doi.org/10.1016/j.anireprosci.2010.12.003

[193] Pandey AK, Ghuman SPS, Dhaliwa GS, Honparkhe M, Phogat JB, Kumar S. Effects of preovulatory follicle size on estradiol concentrations, corpus luteum diameter, progesterone concentrations and subsequent pregnancy rate in buffalo cows (Bubalus bubalis). Theriogenology. 2018; 107: $57-62$

https://doi.org/10.1016/j.theriogenology.2017.10.048

[194] De Carvalho NA, Soares JG, Baruselli PS. Strategies to overcome seasonal anestrus in water buffalo. Theriogenology 2016; 86(1): 200-6. https://doi.org/10.1016/j.theriogenology.2016.04.032

[195] Balamurugan B, Karuthadurai T, Ramamoorthy M, Jena D. Manipulation of estrous cycle to improve reproductive efficiency in cattle and buffalo. Int J Livest Res 2017; 8(1): 19-31. https://doi.org/10.5455/ijlr.20170816073820

[196] Gutiérrez-Añez JC, Palomares RA, Jiménez- Pineda JR, Camacho AR, Portillo-Martínez GE. Pregnancy rate in water buffalo following fixed-time artificial insemination using new or used intravaginal devices with two progesterone concentrations. Trop Anim Health Prod 2017; 50(3): 629-634 https://doi.org/10.1007/s11250-017-1479-1

[197] Monteiro BM, de Souza DC, de Carvalho NAT, Baruselli PS. Effect of season on dairy buffalo reproductive performance when using P4/E2/eCG-based fixed-time artificial insemination management. Theriogenology 2018; 119: 275281.

https://doi.org/10.1016/j.theriogenology.2018.07.004
[198] Ahmad N, Arshad U. Synchronization and resynchronization strategies to improve fertility in dairy buffaloes. Theriogenology 2020; 150: 173-179 https://doi.org/10.1016/j.theriogenology.2020.01.025

[199] Terzano GM, Barile VL, Mongiorgi S, Borghese A. Effeto di diversi livelli alimentari sulla pubertà in bufale di razza Mediterranea. Atti 47o Conv. S.I.S. Vet. 1993; Riccione: 1803-1807.

[200] Bodla MT, Anwar M, Ahmad E, Naseer Z, Ahsan U. Effect of two management systems and mineral feeding on age at puberty in Nili-Ravi buffalo heifers. Buffalo Bulletin 2017; 36(1): 27-33.

[201] Zicarelli L. Management in different environmental conditions. Buf J 1994; Suppl. 2: 17-38.

[202] Borghese A, Barile VL, Terzano GM, Pilla AM, Parmeggiani A. Melatonin trend during season in heifers and buffalo cows. Bubalus Bubalis 1995; 1: 61-65

[203] Cerón-Muñoz MF, Agudelo-Gómez DA, Ramírez-Arias JP. Estacionalidad de partos de búfalas en Colombia. Livest Res Rural Dev 2017; 29: Article 38. http://www.lrrd.org//rrd29/2/cero29038.html

[204] Baruselli PS. Manejo reprodutivo de bubalinos. Inst. Zoot. Estacao Esperimental de Zootecniq do Vale do Ribeira, Registro SP., Brazil, 1993.

[205] Abdel-Latif MA, El-Gohary ES, Gabr AA, El-Hawary AF, Ahmed SA, Ebrahim SA, Fathala MM. Impact of supplementing propylene glycol and calcium propionate to primiparous buffalo cows during the late gestation and early lactation period on reproductive performance and metabolic parameters. Alex J Vet Sci 2016; 51(1): 114-121. https://doi.org/10.5455/ajvs.240341

[206] Hansen HH, El-Bordeny NE, Ebeid HM. Response of primiparous and multiparous buffaloes to yeast culture supplementation during early and mid-lactation. Animal Nutrition 2017; 3: 411-418. https://doi.org/10.1016/j.aninu.2017.08.005

[207] Ahmad Para I, Ahmad Shah M, Punetha M, Hussain Dar A, Rautela A, Gupta D, Singh M, Ahmad Naik M, Rayees M, Sikander Dar P, Ahmad Malla B. Feed fortification of periparturient Murrah buffaloes with dietary yeast (Saccharomyces cerevisiae) elevates metabolic and fertility indices under field conditions. Biol Rhythm Res 2019. https://doi.org/10.1080/09291016.2018.1557834

[208] Zicarelli L. Note comparative di fisiopatologia della riproduzione tra le specie bovina e bufalina. Proc Giornate Buiatriche 1997; p. 84-104.

[209] Nazir G, Ghuman SP, Singh J, Honparkhe M, Ahuja CS, Dhaliwal GS, Sangha MK, Saijpaul S, Agarwal SK. Improvement of conception rate in postpartum flaxseed supplemented buffalo with Ovsynch+CIDR protocol. Anim Reprod Sci 2013; 137(1-2): 15-22. https://doi.org/10.1016/j.anireprosci.2012.11.012

[210] Ezzo OH. The effects of vitamins and Se supplementation on serum vitamin level and some reproductive patterns in Egyptian buffaloes during pre and postpartum periods. Buffalo Journal 1995; 11: 103-107.

[211] Panda N, Kaur H, Mohanty TK. Reproductive performance of dairy buffaloes supplemented with varying levels of vitamin E. Asian-Australas J Anim Sci 2006; 19: 19-25.

[212] Reddy NA, Venkata Seshiah Ch, Sudhakar K, Srinivasa Kumar D, Kanth Reddy PR. Effects of shortened dry period on the physical indicators of energy reserves mobilization in high yielding Murrah buffaloes. Indian J Anim Res 2018; 52(11): 1656-1660.

https://doi.org/10.18805/ijar.B-3406

[213] Viana RB, Monteiro MB, Cardoso Da Cruz E, Ribeiro Filho JD, Albuquerque RDS, Albuquerque de Melo PM, Baruselli PS. Can mineral supplementation modify the characteristics 
of young buffalo ejaculate? Semina: Ciências Agrárias, Londrina 2019; 40(5): 2271-2286.

https://doi.org/10.5433/1679-0359.2019v40n5Supl1p2271

[214] Garb AAW, El Basuini MF. Effect of tonophosphan, zinc oxide, and ascorbic acid on semen, sexual desire, and the fertility rate of Egyptian buffalo bulls. Annals Agric Sci 2018; 63: 215-221.

https://doi.org/10.1016/j.aoas.2018.12.001

[215] Singh PK, Kamboj ML, Kumar N. Effect of dummy calf, weaning and suckling on the reproductive performance of post-partum Murrah buffaloes. Indian J Anim Res 2016; 50 (2): 265-267. https://doi.org/10.18805/ijar.9298

[216] De la Cruz-Cruz LA, Bonilla-Jaime H, Orozco-Gregorio H, Tarazona-Morales AM, Ballesteros-Rodea G, RoldanSantiago P, Waytula M, Vargas-Romero JM. Effects of weaning on the stress responses and productivity of water buffalo in different breeding systems: a review. Livest Sci 2019; 226: 73-81. https://doi.org/10.1016/j.livsci.2019.05.020

[217] Shalaby NA, Oudah EZM, El-Sharkawy YMS. Comparison between some productive and reproductive traits and genetic parameters in the first three lactations in Egyptian buffaloes. J. Animal and Poultry Prod Mansoura Univ 2016; 7(3): 113119.

[218] Lucy MC. Symposium review: Selection for fertility in the modern dairy cow-Current status and future direction for genetic selection. J Dairy Sci 2019; 102(4): 3706-3721. https://doi.org/10.3168/jds.2018-15544

[219] Jenkins GM, Amer P, Stachowicz K, Meier S. Phenotypic associations between gestation length and production, fertility, survival, and calf traits. J Dairy Sci 2016: 99: 418426 https://doi.org/10.3168/jds.2015-9934

[220] Gobikrushanth M, Bruinjé TC, Colazo MG, Butler ST, Ambrose DJ. Characterization of anogenital distance and its relationship to fertility in lactating Holstein cows. J Dairy Sci 2017; 100: 9815-9823.

https://doi.org/10.3168/jds.2017-13033

[221] Akbarinejad V, Gharagozlou F, Vojgani M, Shourabi E, Makiabadi MJM. Inferior fertility and higher concentration of anti-Müllerian hormone (AMH) in dairy cows with longer anogenital distance (AGD). Dom Animal Endocrinol 2019; 68: 47-53.

https://doi.org/10.1016/j.domaniend.2019.01.011

[222] Gobikrushanth M, Purfield DC, Kenneally J, Doyle RC, Holden SA, Martinez PM, Rojas Canadas E, Bruinjé TC, Colazo MG, Ambrose DJ, Butler ST. The relationship between anogenital distance and fertility, and genome-wide associations for anogenital distance in Irish Holstein-Friesian cows. J Dairy Sci 2019; 102: 1-10 https://doi.org/10.3168/jds.2018-15552

[223] Dechow, CD, Rogers GW, Clay JS. Heritability and correlations among body condition score loss, body condition score, production and reproductive performance. J Dairy Sci 2002; 85: 3062-3070.

https://doi.org/10.3168/jds.S0022-0302(02)74393-2
[224] Berry DP, Buckley F, Dillon P, Evans RD, Rath M, Veerkamp RF. Genetic parameters for body condition score, body weight, milk yield, and fertility estimated using random regression models. J Dairy Sci 2003; 86: 3704-3717. https://doi.org/10.3168/jds.S0022-0302(03)73976-9

[225] Weigel KA. Prospects for improving reproductive performance through genetic selection. Anim Reprod Sci 2006; 96: 323-330. https://doi.org/10.1016/j.anireprosci.2006.08.010

[226] Moore SG, Fair T, Lonergan P, Butler ST. Genetic merit for fertility traits in Holstein cows: IV. Transition period, uterine health, and resumption of cyclicity. J Dairy Sci 2014; 97: 2740-2752.

https://doi.org/10.3168/jds.2013-7278

[227] Dash S, Chakravarty AK, Singh A, Upadhyay A, Singh M, Yousuf S. Effect of heat stress on reproductive performances of dairy cattle and buffaloes: A Review. Veterinary World 2016; 9(3): 235-244.

https://doi.org/10.14202/vetworld.2016.235-244

[228] Zicarelli L. Influence of seasonality on buffalo production. In: Precisse GA, editor. The Buffalo (Bubalus bubalis)Production and Research. Sharjah, UAE: Bentham Science Publishers; 2017; p.196-224.

[229] Das GK, Khan FA. Summer anoestrus in buffalo-a review. Reprod Dom Anim 2010; 45(6): e483-e494. https://doi.org/10.1111/j.1439-0531.2010.01598.x

[230] Rao TKS, Kumar N, Kumar P, Chaurasia S, Patel NB. Heat detection techniques in cattle and buffalo. Veterinary World 2013; 6(6): 363-369. https://doi.org/10.5455/vetworld.2013.363-369

[231] Barile LV. Technologies related with the artificial insemination in buffalo. J Buffalo Sci 2012; 1: 139-146.

[232] Zicarelli L. Considerations on the breeding and weaning of buffalo calf. J Buffalo Sci 2020; 9: 84-91.

[233] Campanile G, Di Palo R, Infascelli F, Gasparrini B, Neglia G Zicarelli F, D'Occhio MJ. Influence of rumen protein degradability on productive and reproductive performance in buffalo cows. Repr Nutr Dev 2003; 43: 557-566.

[234] Campanile G, Neglia G, Di Palo R, Gasparrini B, Pacelli C, D'Occhio MJ, Zicarelli L. Relationship of body condition score and blood urea and ammonia to pregnancy in Italian Mediterranean buffaloes. Reprod Nutr Dev 2006; 46: 57-62.

[235] Mujibi FDN, Crews DH. Genetic parameters for calving ease, gestation length, and birth weight in Charolais cattle. J Anim Sci 2009; 87 (9): 2759-2766. https://doi.org/10.2527/jas.2008-1141

[236] Norman HD, Wright JR, Kuhn MT, Hubbard SM, Cole JB, VanRaden, PM. Genetic and environmental factors that affect gestation length in dairy cattle. J Dairy Sci 2009; 92(5): 2259-2269. https://doi.org/10.3168/jds.2007-0982

\section{DOI: https://doi.org/10.6000/1927-520X.2020.09.15}

(c) 2020 Nava-Trujillo et al.; Licensee Lifescience Global.

This is an open access article licensed under the terms of the Creative Commons Attribution Non-Commercial License (http://creativecommons.org/licenses/by-nc/3.0/) which permits unrestricted, non-commercial use, distribution and reproduction in any medium, provided the work is properly cited. 